\title{
Morphological dynamics of an englacial channel
}

\author{
Geir Vatne $^{1}$ and Tristram D. L. Irvine-Fynn ${ }^{2}$ \\ ${ }^{1}$ Department of Geography, Norwegian University of Science and Technology (NTNU), 7491 Trondheim, Norway \\ ${ }^{2}$ Centre for Glaciology, Department of Geography and Earth Sciences, Aberystwyth University, Aberystwyth, SY23 3DB, UK \\ Correspondence to: Geir Vatne (geir.vatne@ svt.ntnu.no)
}

Received: 11 June 2015 - Published in Hydrol. Earth Syst. Sci. Discuss.: 7 August 2015

Revised: 17 April 2016 - Accepted: 2 June 2016 - Published: 21 July 2016

\begin{abstract}
Despite an interest in the hydraulic functioning of supraglacial and englacial channels over the last 4 decades, the processes and forms of such ice-bounded streams have remained poorly documented. Recent glaciological research has demonstrated the potential significance of so-called "cutand-closure" streams, where englacial or subglacial flow paths are created from the long-term incision of supraglacial channels. These flow paths are reported to exhibit step-pool morphology, comprising knickpoints and/or knickzones, exaggerated in dimensions in comparison to supraglacial channels. However, little is known of the development of such channels' morphology. Here, we examine the spatial organisation of step pools and the upstream migration of steps, many of which form knickzones, with repeated surveys over a 10-year period in an englacial conduit in cold-based Austre Brøggerbreen, Svalbard. The observations show upstream step recession to be the dominant process for channel evolution. This is paralleled by an increase in average step height and conduit gradient over time. Characteristic channel-reach types and step-riser forms are consistently observed in each of the morphological surveys reported. We suggest that the formation of steps has a hydrodynamic origin, where steppool geometry is more efficient for energy dissipation than meanders. The englacial channel system is one in rapid transition towards a quasi-equilibrium form within a decadal timescale. The evolution and recession of knickzones reported here result in the formation of a $37 \mathrm{~m}$ deep moulin shaft, suggesting that over time an incising supraglacial channel may evolve towards an englacial channel form exhibiting a stable end-point characterised by a singular vertical descent, which potentially can reach the glacier bed. This challenges the prevailing notions that crevasses or hydrofractures are needed to form deep moulins. Our observations highlight the need to further examine the adjustment processes in cut-
\end{abstract}

and-closure channels to better understand their coupling to supraglacial meltwater sources and potential significance in cold-based glacier hydrology and ice dynamics.

\section{Introduction}

Fluvial geomorphologists have long been intrigued by the similarities between supraglacial and alluvial streams when it comes to meandering, especially as ice walled streams typically lack an entrained sediment load (Dozier, 1976; Knighton, 1972; Leopold et al., 1960; Zeller, 1967), and are typically characterised by a rapidly adjusting morphology (Dozier, 1974). This observation in turn motivated research focused on the controlling factors of form, meandering and adjustment of ice walled channels including both the extrinsic influences of glacier ice structure and rheology (Dozier, 1974; Ferguson, 1973; Hambrey, 1977) and intrinsic processes associated with water flow (Dozier, 1976; Ferguson, 1973; Knighton, 1981; Marston, 1983; Parker, 1975; Pinchak, 1972). Supraglacial observations have suggested that intrinsic processes also lead to the formation of staircase-like longitudinal profiles or step-pool sequences (Carver et al., 1994; Knighton, 1985, 1981); such features appear similar to the forms commonly found both in bedrock rivers (Hayakawa and Oguchi, 2006; Howard, 1998; Whipple and Tucker, 2002; Wohl and Grodek, 1994) and highgradient alluvial channels (Abrahams et al., 1995; Chin, 1998; Church and Zimmermann, 2007; Comiti et al., 2009; Grant et al., 1990; Molnar et al., 2010; Turowski et al., 2009).

The term "step pool" is commonly used for channel forms with alternating channel-spanning convexities (steps or knickpoints) and concave pools (Peterson and Mohanty, 1960). Such morphological form is thought to be a char- 
acteristic of streams with slopes $>2 \%$ (Chin, 1989; Grant et al., 1990; Montgomery and Buffington, 1997) and may represent a process akin to meandering in the vertical dimension (Chin, 2002; Kostrzewski and Zwoliñski, 1995). Indeed, recent work on bedrock rivers (Hayakawa and Oguchi, 2014) suggests step-pool sequences may be related to intrinsic channel hydraulics and flow perturbations rather than more commonly cited extrinsic environmental controls (Phillips et al., 2010). Consequently, due to the rapidity of morphological adjustment in ice, supraglacial and englacial streams represent natural, experimental opportunities to investigate hydrodynamic processes of channel adjustment and meandering in both the horizontal and vertical dimensions. Despite this potential, the hydraulics and morphology of supraglacial streams have received surprisingly little attention over the last 25 years, despite a recent resurgence (Isenko and Mavluydov, 2002; Isenko et al., 2005; Jarosch and Gudmundsson, 2012; Karlstrom et al., 2013; Kostrzewski and Zwoliñski, 1995; Mantelli et al., 2015; Raymond and Nolan, 2000; Smith et al., 2015; Stock and Pinchak, 1995).

Although rarely described specifically in the literature, step-pool geometry analogous to that found in supraglacial channels is widely reported in speleological investigations of englacial flow paths and conduits (Griselin, 1992; Holmlund, 1988; Piccini et al., 2000; Pulina, 1984; Pulina and Rehak, 1991; Řehák et al., 1990; Schroeder, 1998; Vatne, 2001; Vatne and Refsnes, 2003). The prevalence of the steps (typically $1-5 \mathrm{~m}$ in height) in englacial flow paths may mean that $>80 \%$ of an englacial conduits' vertical descent occurs in cascades (e.g. Vatne, 2001). Recent studies have referred to individual steps in the longitudinal channel profiles as knickpoints (e.g. Gulley, 2009). At these knickpoints, where slopes are steepest, hydrodynamic theory predicts heightened melt rates (Isenko and Mavluydov, 2002), and direct observations have reported that erosion rates at steps cause headward recession of the channel floor at rates of up to $47 \mathrm{~cm} \mathrm{day}^{-1}$ (Gulley et al., 2009a). However, to date, the temporal evolution of the longitudinal profile of englacial conduits has rarely been described, and the formative processes of step pools in englacial environments have not been addressed in detail.

The continued interest in the hydraulics of ice-bounded streams arises because the long-standing assumption that englacial drainage is conditioned by hydraulic potential (Shreve, 1972) has given way to the realisation that ice structure, in the form of crevasses, fractures, debris intrusions and variations in hydraulic permittivity (Gulley, 2009; Gulley and Benn, 2007; Mavlyudov, 2005; Stenborg, 1968) may be hydrologically significant. This insight is coupled with the recognition that hydrologically assisted fracture propagation (Benn et al., 2009; Boon and Sharp, 2003; Hambrey, 1984) and the progressive incision of so-called cut-and-closure supraglacial streams (Gulley et al., 2009a; Vatne, 2001) also represent important mechanisms by which meltwater can be transferred from the supraglacial environment to a glacier's interior (Bælum and Benn, 2011; Naegeli et al., 2014). With suggestions that englacial flow paths, particularly in nontemperate ice masses, may be comparable with karstic systems (e.g. Clayton, 1964; Gulley et al., 2009b; Mavlyudov, 2006), it is likely channel evolution in these open-flow systems is largely controlled by hydrodynamic processes. Consequently, improving the current state of knowledge with respect to the evolving morphology of meltwater flow paths is an important avenue for research.

Here, this paper aims to develop ideas presented by Vatne and Refsnes (2003) to further examine the characteristics and evolution of englacial conduits with a focus on step-pool segments, their upstream migration and the hydrodynamic controls of channel evolution. Using the accessible section of an englacial conduit in Austre Brøggerbreen, Svalbard, we provide a detailed analysis based on direct observations made during five surveys over a 10 -year period. Comparisons drawn with research in alluvial and bedrock stream systems address two key questions:

i. Do englacial conduits exhibit time-invariant morphological characteristics?

ii. Which factors control knickpoint step gradient and upstream recession rate?

These questions provide the basis for a conceptual model of the proposed process - form linkages, and advance our understanding of the causal mechanisms, development, and maintenance of englacial channels.

\section{Theoretical context}

\subsection{Knickzones, knickpoints, and step pools: character and stability}

Within studies of fluvial incision in bedrock and the associated evolution of longitudinal profiles of rivers, the term "knickpoint" has a long history, representing singular features of abrupt slope changes (Davis, 1932; Haviv et al., 2010; Hayakawa and Oguchi, 2009; Holland and Pickup, 1976; Penck, 1925; Whipple et al., 2000). However, the term knickpoint has also been used to encompass the locally specific point of marked change in channel-bed slope, and the associated steepened channel reach (e.g. Whipple, 2004). Reaches that are significantly steeper than adjacent reaches, comprising both steep, critical and gentle stream segments, or a cataract of multiple knickpoints, may be termed knickzones (e.g. Hayakawa and Oguchi, 2006; Richardson et al., 2005; Wohl, 2013) (Fig. 1). Series of knickpoints or knickzones along a channel often appear as "wave trains" that may exhibit regular frequency or density (e.g. Chin, 2003; Loget and Van Den Driessche, 2009). Both knickpoints and knickzones migrate upstream by erosion rates that exceed those of adjacent reaches (Hayakawa and Matsukura, 
2003, 2010; Wohl, 1993; Wohl et al., 1999). This has been suggested to be the dominant mode of channel adjustment, in response to either regional or local perturbation (Bishop et al., 2005; Larue, 2008; Shumm et al., 2000). Channel profile development from the progressive headward recession of knickpoints, whose rates of adjustment may be varied, has been referred to as the wave train model (Loget and Van Den Driessche, 2009). However, there is no consensus as to the origin and shape of knickpoints or the mechanisms causing knickpoint recession in bedrock channels across annual to millennial timescales (e.g. Baynes et al., 2015; Castillo et al., 2013; Cook et al., 2013; Crosby and Whipple, 2006; Hayakawa and Oguchi, 2014; Phillips and Desloges, 2013; Sklar and Dietrich, 2001; Whittaker et al., 2007). It is argued that knickpoint propagation is controlled by discharge and the contributing drainage area (e.g. Bishop et al., 2005; Crosby and Whipple, 2006; Loget and Van Den Driessche, 2009) and that substrate characteristics influence both the recession rate and shape of the knickpoint face (Gardner, 1983; Larue, 2008; Phillips and Desloges, 2013).

Step pools form major geomorphological elements in knickzones in both bedrock (Miller, 1991; Wohl et al., 1999) and alluvial rivers (Chin, 1998; Chin and Phillips, 2007; Chin and Wohl, 2005; Wohl et al., 1999). A step-pool channel element consists of two components: an initial steep segment, and a downstream plunge pool. The channel-spanning steep segment is often termed the "step riser" (Chartrand and Whiting, 2000) (Fig. 1), defined as a critical slope segment preceded and followed by a shallow slope segment (Milzow et al., 2006). Commonly, the step riser is proceeded by a pool segment that is characterised by gradual changes in flow, although the high-velocity plunging flow or jet can cause erosional scour, thereby influencing pool geometry (Stein et al., 1993) and secondary circulation patterns (Venditti et al., 2014). Step pools form a series of distinct hydraulic conditions (Dust and Wohl, 2012), transitioning from subcritical flow upstream of the step (or knickpoint), to critical flow across the knickpoint lip, supercritical flow through the step riser, and a turbulent plunge pool downstream that contains a hydraulic jump (Church and Zimmermann, 2007). They serve a fundamental role in steep streams because the steps reinforce bed stability (Church, 2002), and provide much of the elevation drop and channel roughness (Ashida et al., 1976; Chin, 1998; Whittaker, 1987).

Despite the importance of step-pool sequence geometries, surprisingly limited work has been conducted on different step morphologies or the character of the different types of jets and hydraulic jumps that occur in natural channels (Carling et al., 2005; Vallé and Pasternack, 2006; Wilcox et al., 2011), and the morphologies that they produce. Natural jets, where water flow changes from subcritical to supercritical, are reported to be (i) channel-bed-supported sloping jets, or (ii) ballistic nappe flow, which is characterised by a freefall water jet impinging on the downstream pool (Fig. 1). Downstream, within the subcritical pool segment, hydraulic

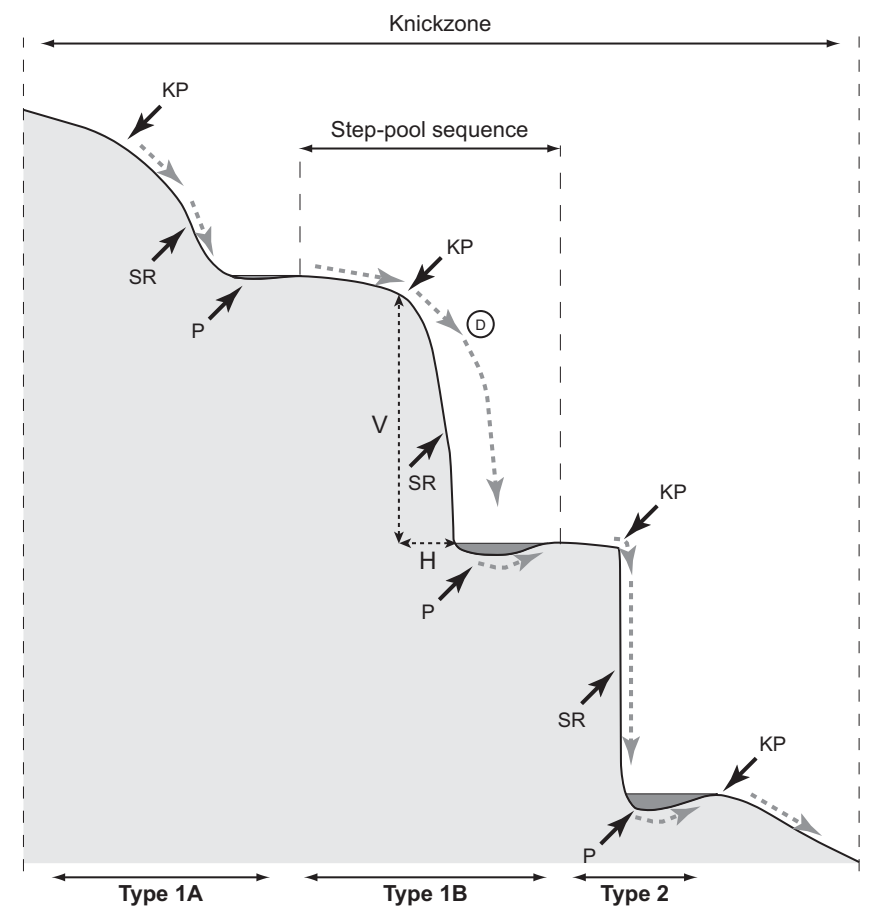

Figure 1. Schematic to illustrate step-pool sequences and the terminology for knickzone (KZ) morphology including step riser (SR), pool (P), and knickpoint (KP); $D$ denotes flow detachment, while $V$ and $H$ reflect vertical and horizontal step dimensions respectively. Note the classification of step form type (1A, 1B, and 2) used in this paper.

jumps are observed to be both submerged and unsubmerged, controlled by the ratio of upstream hydraulic head and stepriser height relative to the pool or tailwater depth (Peterka, 1963; Vallé and Pasternack, 2006). For a knickzone where a succession of high steps is found, water flow typically decouples from the step risers and nappe flow dominates (Chanson, 1994). Under such conditions, energy is dissipated both by free-jet break-up in the air, by jet impact on the pool surface, and within the associated hydraulic jump (Chanson, 1994; Vallé and Pasternack, 2006). For sloping jets, energy dissipation processes differ from that of ballistic jets, with greater influence of channel-bed roughness and friction. Vallé and Pasternack (2006) observed dichotomous hydraulic responses to a change in discharge for both sloping and ballistic jets: the projection length of the ballistic jet increased by $60 \%$ in response to a doubling of discharge, but decreased by $20 \%$ for the sloping jet. The effect of this is that the impact point of a ballistic jet changes more markedly with discharge (Mason and Arumugam, 1985; Stein et al., 1993), and will affect plunge pool geometry through the resulting flow circulation patterns (Venditti et al., 2014).

Independent from the types of jet and hydraulic jump, knickzones provide exceptionally high hydraulic resistance and heat dissipation, and it has been argued that step-pool morphology is mutually adjusted with flow and energy ex- 
penditure (Abrahams et al., 1995; Chin, 2003; Curran and Wohl, 2003). Curran and Wohl (2003) assessed the relative influence of various channel elements on flow resistance in step-pool streams, and concluded that spill resistance, resulting from a sudden change in velocity where local flow rapidly transitions from supercritical to (sub)critical, causes intense energy dissipation (Leopold et al., 1960). Such dissipation mechanisms may account for up to $90 \%$ of total flow resistance (Curran and Wohl, 2003). The energy loss from steps depends on step size and discharge; small steps may be drowned out during high discharge when skimming flow dominates, a situation where energy dissipation is much less than under nappe flow conditions (Chanson, 1994).

\subsection{Channels in ice}

In supraglacial streams, helical flow promotes meandering and results in a channel sinuosity inversely related to channel slope and stream power (Ferguson, 1973; Knighton, 1981; Marston, 1983). The at-a-station hydraulic geometry of supraglacial channels tends to respond to increases in discharge, with heightened increases in flow velocity relative to changes in the cross-sectional flow area (Knighton, 1981; Kostrzewski and Zwoliñski, 1995; Marston, 1983). Meltwater channel incision into, and lateral migration within, glacier ice results from heat exchange between flowing water in the channel and the ice walls. The melt rate $\left(M\right.$, in $\left.\mathrm{m} \mathrm{s}^{-1}\right)$ associated with the flowing water can be estimated as

$M=\frac{B v \Delta T}{\rho_{\mathrm{i}} L_{\mathrm{f}}}$,

where heat exchange is governed by the temperature difference $(\Delta T)$ and water velocity $(v), B$ is $2.64 \times 10^{3} \mathrm{~J} \mathrm{~m}^{-3} \mathrm{~K}^{-1}$ for turbulent flow at $0^{\circ} \mathrm{C}$ (Lock, 1990), and melting accounts for ice density $\left(\rho_{\mathrm{i}}=900 \mathrm{~kg} \mathrm{~m}^{3}\right)$ and the latent heat of fusion $\left(L_{\mathrm{f}}=334 \mathrm{~kJ} \mathrm{~kg}^{-1}\right)$. More detailed numerical modelling approaches to this process are detailed by Jarosch and Gudmundsson (2012), Karlstrom et al. (2013) and Mantelli et al. (2015). Isenko et al. (2005) showed theoretically that, in the absence of external energy (air temperature and incident radiation), water temperature in a straight ice-walled channel with a constant gradient will reach a positive equilibrium temperature, whereby the warming effect of viscous flow balances heat loss to the ice; this was in agreement with laboratory experiments. In the supraglacial environment, a meltwater temperature of $0.005-0.01{ }^{\circ} \mathrm{C}$ can account for rates of vertical incision between 20 and $58 \mathrm{~mm} \mathrm{day}^{-1}$ (Marston, 1983; Pinchak, 1972). However, due to the dependence between slope and water flow velocity, as slopes increase, so too do equilibrium water temperatures and potential incision rates. Field observations of supraglacial stream water temperature suggest that heat generated by viscous flow is rapidly lost to the surrounding ice, as water temperatures are found to be between 0 and $0.4{ }^{\circ} \mathrm{C}$ (Isenko et al., 2005).
Parker (1975) identified that ice-walled channel incision results from a combination of hydrodynamic and thermal processes. Nonetheless, despite being quantified, the relative proportions of channel down cutting due to atmospheric heat fluxes and frictional heating remain equivocal (cf. Dozier, 1976; Marston, 1983; Pinchak, 1972; Stock and Pinchak, 1995). Pinchak (1972) notes that the steep channel gradients needed for frictional heat genesis are not necessarily common on glacier surfaces. Yet, channel meandering can develop for both low (e.g. Knighton, 1981) and high (e.g. Brykała, 1998) gradient supraglacial channels. Field-based observations of meandering and step-pool sequences (Carver et al., 1994; Knighton, 1985, 1981) and numerical simulations (Karlstrom et al., 2013; Mantelli et al., 2015), highlight that hydraulic instabilities affect channel form. The conditions controlling unstable, supercritical flow and its association with existing and/or resultant channel morphology is not well understood (Mantelli et al., 2015). Considerable uncertainty still remains over the transitions between meandering to stepped supraglacial channel profiles, the coexistence of such channel geometries, and the relationship of channel form to surface slope. Therefore, it can be seen that the nature of glacial channel adjustment in three dimensions and over time remains poorly constrained (Irvine-Fynn et al., 2011).

In climatic settings where stream channel incision outpaces general glacier surface ablation, supraglacial streams may progressively deepen and become entombed englacially, due to snow bridging or progressive ice creep closure of the inactive near-surface channel boundaries (Fountain and Walder, 1998; Gulley et al., 2009a; Irvine-Fynn et al., 2011; Röthlisberger and Lang, 1987). These cut-and-closure channels can continue to incise under open-flow conditions. However, in the englacial environment, stream waters are separated from meteoric influences, and heat transfer from kinetic energy and friction plays a more prominent role in channel adjustment. The loss of potential energy by flowing water, assuming conservation of energy, can increase water temperature at a rate of $0.002{ }^{\circ} \mathrm{C} \mathrm{m}^{-1}$ in the vertical dimension (Isenko et al., 2005; Zotikov, 1982: cited in Isenko, 2006). A water temperature profile recorded for an englacial channel with 14 step-pool sequences descending $57 \mathrm{~m}$ suggested that rates of water temperature increase may be higher than theoretically expected (Isenko, 2006) with resulting increases in stream incision rates downstream. However, it is important to recall that englacial channels are also subject to creep closure as the ice responds to effective stresses: the rate of closure is dependent on the depth of overlying ice, local ice temperature, and the in-channel water pressure (Evatt, 2015; see also Jarosch and Gudmundsson, 2012; Nye, 1953). Consequently, both open-channel and pressurised flow conditions may occur in englacial flow paths. However, a number of studies have shown that englacial channels can remain open to great depths, even at the end of the winter, with cross-sectional areas precluding pressurised flow conditions (Gulley, 2009; Gulley et al., 2009a; e.g. Pulina, 1984; Pulina and Rehak, 


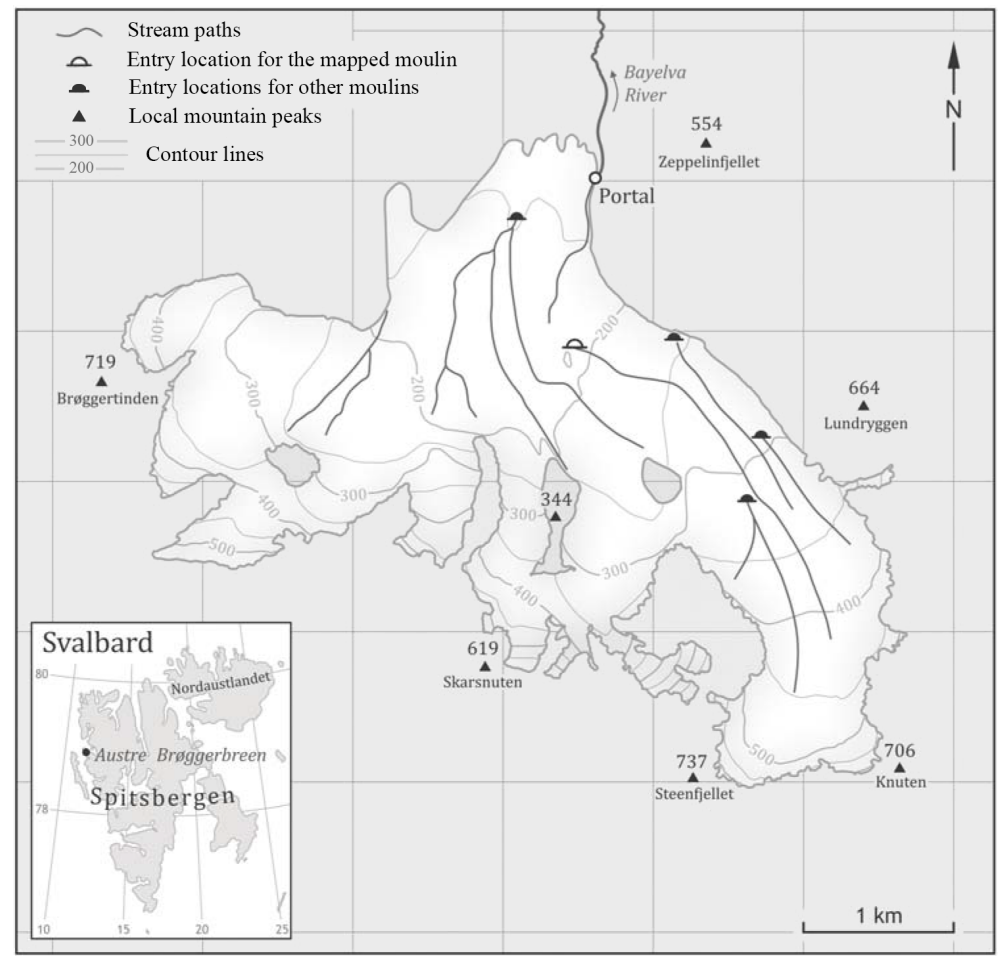

Figure 2. Location map of Austre Brøggerbreen. Contour lines are based on a 1990 elevation data set, with the glacier area according to König et al. (2013). Location of moulins and the portal, which is where the main meltwater stream emerges from within the glacier, are from autumn 2004.

1991; Schroeder, 1998, 1994; Vatne, 2001; Vatne and Refsnes, 2003).

\section{Field site and methods}

\subsection{Austre Brøggerbreen}

Austre Brøggerbreen $\left(78^{\circ} 55^{\prime} \mathrm{N}, 11^{\circ} 46^{\prime} \mathrm{E}\right)$ is a $10 \mathrm{~km}^{2}$ northfacing valley glacier in north-western Svalbard extending from $\sim 80$ to $600 \mathrm{~m}$ a.s.l. (Fig. 2). With a long-term negative net balance of $-0.4 \mathrm{~m}$ waterequivalent (w.e.) $\mathrm{a}^{-1}$ since 1967 (Hagen and Lefauconnier, 1995), and current thinning rates of $-0.6 \mathrm{mw}$.e. $\mathrm{a}^{-1}$, the glacier is downwasting rapidly in both its ablation and accumulation areas (Barrand et al., 2010; James et al., 2012). Consequently, maximum thickness of glacier ice is now $<100 \mathrm{~m}$ (cf. Björnsson et al., 1996), and ice velocity is low at $<3 \mathrm{ma}^{-1}$ (Hagen and Liestøl, 1990). Temperature profiles show that the glacier ice reaches $0^{\circ} \mathrm{C}$ at depths of $\sim 80 \mathrm{~m}$ (Hagen et al., 1991), and the glacier is now assumed to be cold-based (cf. Björnsson et al., 1996). The dominant, easternmost flow unit descending from Steenfjellet to the glacier terminus (Fig. 2) is characterised by scarce, spatially restricted relict transverse fracture traces, typically clear ice of a few centimetres in width; active, open crevasses are absent (Jennings et al., 2015). As is common for many small high-latitude valley glaciers, Austre Brøggerbreen's drainage system is predominantly supraglacial, characterised by deeply incised surface streams and a few isolated moulins (Hagen et al., 1991). Seasonal meltwater flow into these moulins enters englacial flow paths with highly variable channel (or conduit) height (2$15 \mathrm{~m}$ ), and 1-3 $\mathrm{m}$ in width (Stuart et al., 2003; Vatne, 2001; Vatne and Refsnes, 2003). One of these conduits experience open-channel (vadose) flow, being 14-90\% water filled during the summer melt season (Stuart et al., 2003). Since they have widths and gradients similar to their upstream supraglacial counterparts, it is reasonable to assume that they experience comparable flow depths $(<0.5 \mathrm{~m})$ for much of the ablation season (Hagen et al., 1991; Stuart et al., 2003; Vatne, 2001). These englacial flow paths are likely to be cut-andclosure channels (Hagen et al., 1991; Vatne, 2001) with typical and consistent englacial through-flow velocities and discharges of $0.1-0.55$ and $1.5-3.5 \mathrm{~m}^{3} \mathrm{~s}^{-1}$ respectively, to the site of meltwater emergence at the ice margin (Holtermann, 2007; Vatne, 2001). Contemporary runoff chemistry confirms the apparent absence of meltwaters draining to or from the glacier's bed (Hodson et al., 2002), and since 1989, there has been no trend in the duration of the meltwater runoff period or summer ablation (Nowak and Hodson, 2013). 


\subsection{Conduit survey measurements}

The longitudinal englacial channel profile from the entrance point approximately 200 ma.s.l. (Fig. 2) was surveyed for the first time in October 1998 (Vatne, 2001), and was resurveyed in April 2000 (Vatne and Refsnes, 2003), spring 2004, 2005 , and 2008. Further ancillary data from a resurvey of the conduit in April 2014 are presented by Myreng (2015). The switch from autumn to spring surveying was to ensure instream pools were frozen, to enable access to greater depths. All surveys, except that in 2004, were halted due to unfrozen pools and water-filled conduit segments rather than impassable channel dimensions.

The position of the entrance for individual channel surveys was determined by Garmin handheld GPS receivers, with an average horizontal accuracy of $15 \mathrm{~m}$ (Garmin, 2015). For all surveys, the morphological assessments were conducted with a laser distance metre (Leica Disto Classic, with precision of $<2 \mathrm{~mm}$ ), a folding rule, and a magnetic compass. Following the methods reported by Gulley and Benn (2007), here, the conduit was divided into linear segments, based on breakpoints in the longitudinal profile (e.g. the foot and crest of a step), or corresponding to limits to a line of sight. The orientation of each segment was measured using a magnetic compass corrected for magnetic deviation, and using forward and back sighting to reduce uncertainties. Channel slope was calculated based on the distance and difference in height between the ends of each measured segment. Channel width was measured at locations considered representative for the reach, either with the laser or folding rule both near the bed, and at 1 and $2 \mathrm{~m}$ above the apparent channel floor respectively, with uncertainties of $<3 \%$ being estimated (see Gulley and Benn, 2007).

Step-riser morphology varied from steep rapids to vertical waterfalls. In this study, rather than arbitrarily define a critical step-riser slope by fitting cumulative distribution functions to observed data (Milzow et al., 2006), steps were provisionally defined as where the vertical elevation change $(V)$ was larger than the concurrent horizontal distance $(H)$ (see Fig. 1), as field observations suggest steps with gentler slopes produce fewer pronounced pools. Each vertical step height was measured from the top of the ice lid in the downstream pool to the top of the knickpoint convexity upstream (Fig. 1). During winter surveys, although approximate pool area could be discerned, conduit air temperatures and water surface freezing precluded access to quantify threedimensional pool geometries. We acknowledge the fact that this also leads to measurement of minimum rather than actual step height, as pool depth is not included; however, observations through the ice lid of a number of pools suggest that the submerged portion of the step height is directly related to total step height. The channel morphology data were then further constrained to reflect step-pool sequences: only steps exhibiting an abrupt downstream increase in channel width, indicating the presence of a hydraulic jump, and ex-

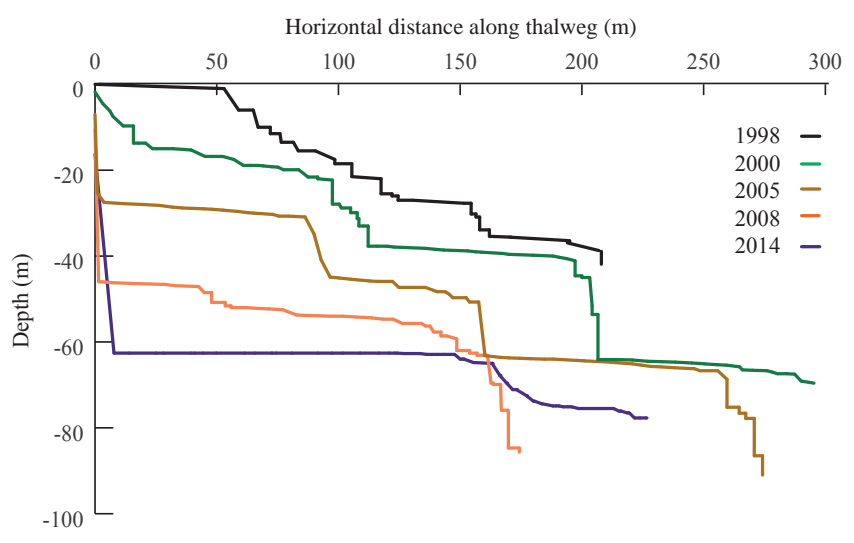

Figure 3. Longitudinal profiles of the englacial channel for individual surveys; all depths are referenced to the 1998 entry location. The data from 2004 are not shown due to significant uncertainty in the position of the entry point relating to the access location through seasonal snow cover. Note that the $x$ axis shows distance measured along the thalweg, not true horizontal distance. Included are data from a resurvey of the conduit in spring 2014 (see Myreng, 2015).

cess energy dissipation, were used in the analyses which follow. Conduit segments that did not fulfil both the step and step-pool criteria were considered simply as channel rapids. Actual conduit height could not be observed in most cases, due to narrow and complex roof geometry and, therefore, was not measured systematically. Except for the channel entrance and the deepest sections of the channel, estimated conduit heights typically exceeded $10 \mathrm{~m}$, yielding cross-sectional areas of $>5 \mathrm{~m}^{2}$.

\section{Results and data analysis}

\subsection{Longitudinal profile evolution and channel-reach characteristics}

The individual profiles for five englacial channel surveys at Austre Brøggerbreen (1998, 2000, 2005, 2008 and 2014) are presented graphically in Fig. 3. The profiles document englacial channel position extending between 42 and $85 \mathrm{~m}$ from the glacier surface, and across horizontal thalweg lengths of $174-301 \mathrm{~m}$. To facilitate direct comparison between surveys, the elevation of the start point of each of the individual surveys has been adjusted relative to the 1998 ice surface elevation. This is done using an annual mean ice surface lowering of $0.9 \mathrm{ma}^{-1}$ at $\sim 200 \mathrm{ma}$.s.l. according to contemporary data from neighbouring Midtre Lovénbreen (Kohler et al., 2007), and accounting for the mean difference between the two glaciers' thinning rates between 1990 and 2003 (Barrand et al., 2010). The accompanying summary data for the profile characteristics are shown in Table 1. Due to the horizontal uncertainty in the absolute location of the conduit entrance, caution must be taken when comparing and 
Table 1. Summary of channel data for individual surveys. $H_{\mathrm{t}}, V_{\mathrm{t}}$, and $S_{\mathrm{A}}$ denotes total horizontal length along thalweg (in $\mathrm{m}$ ), total vertical height (in $\mathrm{m}$ ), and average slope gradient $\left(\mathrm{mm}^{-1}\right)$ respectively. LG, MG, and $\mathrm{KZ}$ denotes number of reaches classified as low gradient, medium gradient, and knickzones respectively. $K_{\mathrm{d}}$ denotes step density calculated as number of steps divided by total channel length along thalweg, and $K_{\mathrm{H}}$ average step height (m).

\begin{tabular}{ccccccccc}
\hline Year & $H_{\mathrm{t}}$ & $V_{\mathrm{t}}$ & $S_{\mathrm{A}}$ & $\mathrm{LG}$ & $\mathrm{MG}$ & $\mathrm{KZ}$ & $K_{\mathrm{d}}$ & $K_{\mathrm{H}}$ \\
\hline 1998 & 208 & 42 & 0.20 & 4 & 1 & 2 & 0.07 & 2.0 \\
2000 & 295 & 68 & 0.23 & 2 & 2 & 3 & 0.04 & 3.3 \\
2004 & 301 & 59 & 0.20 & 3 & 1 & 2 & 0.03 & 5.6 \\
2005 & 274 & 85 & 0.31 & 3 & 1 & 4 & 0.03 & 8.5 \\
2008 & 174 & 77 & 0.44 & 2 & 2 & 2 & 0.08 & 4.8 \\
\hline
\end{tabular}

interpreting changes in horizontal position of individual features from one survey to another using Fig. 3. This positional uncertainty is further compounded by the observed changes in planform (see Sect. 4.3): it must be noted that apparent large upstream horizontal migration in the profile can relate to changes in planform curvature. Nonetheless, data reveal marked changes in channel profile, and specifically the progressive development of a vertical shaft (moulin) descending from the conduit entrance location, apparent lateral recession of step risers and knickzones, and incision of low gradient sections. Low gradient segments interrupted by much steeper knickzones are a characteristic morphology in all surveys.

Here, we define channel reaches as segments more than 10 times the average channel width, with a consistent channel gradient markedly different from the immediate upstream and downstream reaches. Individual reaches are typically delineated by marked breaks in channel gradient. Consequently, three main categories of channel reach were identified in the conduit profile data (Fig. 4): (i) low gradient (LG) reaches with slopes $<0.06 \mathrm{~m} \mathrm{~m}^{-1}$, (ii)medium gradient (MG) reaches exhibiting slopes between 0.06 and $0.5 \mathrm{~m} \mathrm{~m}^{-1}$, and (iii) high-gradient knickzones (KZs) exhibiting slopes $>0.5 \mathrm{~m} \mathrm{~m}^{-1}$. The descriptive statistics for the three categories of channel reach are presented in Table 2 .

The $\mathrm{LG}$ reaches are characterised by very stable gradients across the surveys $\left(X_{\mathrm{w}}=0.04 \mathrm{~m} \mathrm{~m}^{-1}, \sigma_{\mathrm{w}}=0.015 \mathrm{~m} \mathrm{~m}^{-1}\right.$; Table 2), but only account for small quantities of heat dissipation as they are responsible for less than $10 \%$ of the vertical descent, despite representing between 44 and $74 \%$ of the horizontal channel thalweg length. Additionally, the LG reaches display relatively small variations in channel width $(\sigma=0.32 \mathrm{~m})$ consistent across all five surveys (Table 2), insignificant or absent bed roughness elements, and near vertical channel walls (Fig. 4a). The channel widths for MG reaches remained similar over the survey period, but are greater and more variable compared to the LG reaches (Table 2). Coexistent meandering morphologies are commonly observed within the MG reaches (Fig. 4b). Channel width typically more than doubled through channel meander bends,

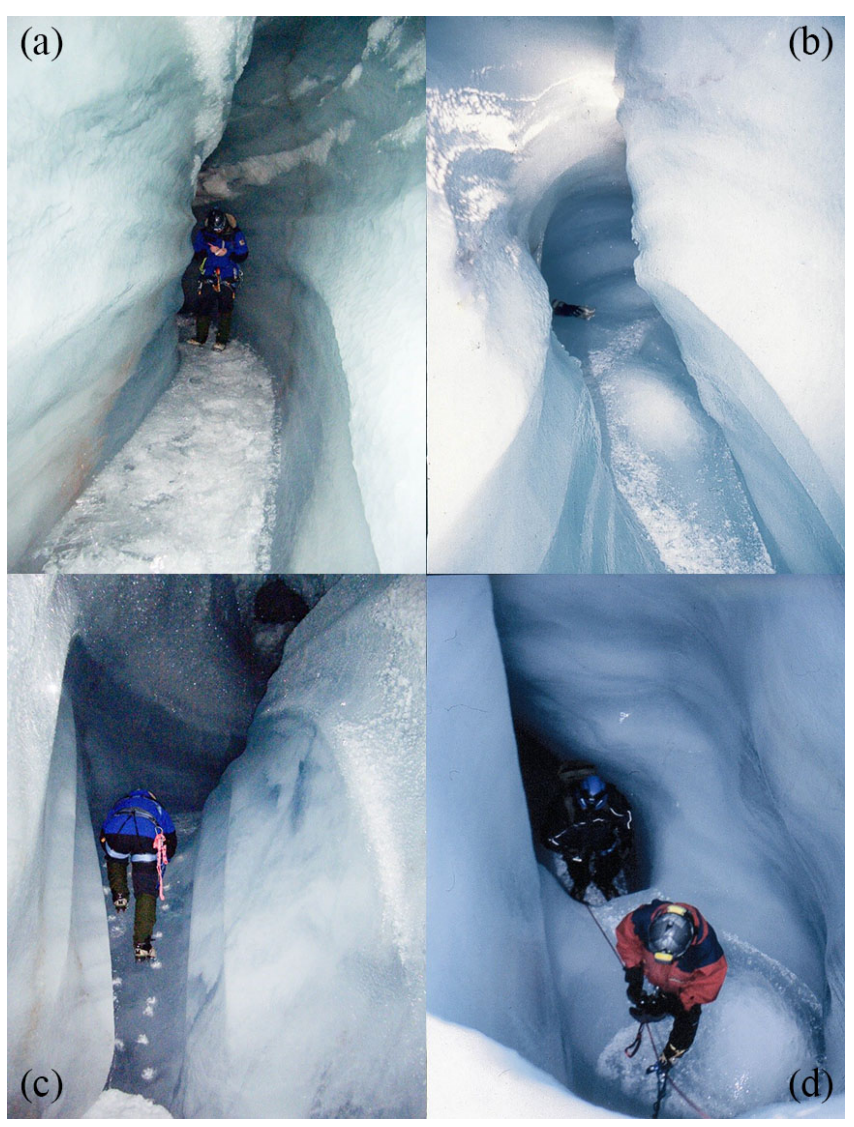

Figure 4. Illustration of various englacial channel forms: (a) low gradient (LG) reach, (b) medium gradient $(\mathrm{MG})$ reach (see glove for scale), (c) knickpoint (KP) with sloping step riser, (d) knickpoints (KP) with vertical step risers. For (c) and (d) compare to KP types 1 and 2 depicted in Fig. 1. For all photos, flow direction is away from the photographer.

and many bends consist of small (typically $\sim 0.3 \mathrm{~m}$ ) steps immediately upstream of a channel curvature, with a small $\left(\sim 1-3 \mathrm{~m}^{2}\right)$ elongated pool forming just upstream of the meander apex and/or throughout the local conduit bend. Singular knickpoints with a vertical step riser of up to $3 \mathrm{~m}$ are also found in the MG reaches. Morphologically, the KZs are the most varied reaches: for all surveys, they are dominated by either a few large or many smaller knickpoints, or step-pool cascades (Fig. 4c, d). Statistics for channel width are not presented for knickzones, as a representative channel width was poorly defined for most step risers, where arguably the definition of channel-bed width is not necessarily hydrologically meaningful, particularly where the jet detaches from the bed (Fig. 1). Channel planform for KZ reaches vary from highly sinuous to almost straight. Knickpoints and knickzones are responsible for a significant proportion of the conduit's vertical descent, typically ranging from 74 to $85 \%$, except for the 1998 channel survey in which they accounted for only $40 \%$ (Table 1). In general, the taller the steps, the larger the fraction of the step riser that is vertical 
Table 2. Statistics of reach characteristics for individual surveys. Here, $n$ denotes number of reaches in the survey, $H \%$ and $V \%$ denotes the percentage of the horizontal and vertical distance of the total surveyed channel length by the different reach types. $S$ denotes slope, and $X_{\mathrm{W}}$ and $\sigma_{\mathrm{w}}$ represent mean channel width and standard deviation respectively. Note, the channel geometry of KZ reaches often precluded the robust measurement of a meaningful channel width.

\begin{tabular}{|c|c|c|c|c|c|c|c|c|c|c|c|c|c|c|}
\hline \multicolumn{5}{|c|}{ LG } & \multicolumn{5}{|c|}{ MG } & \multicolumn{5}{|c|}{$\mathrm{KZ}$} \\
\hline Year & $n$ & $H \%$ & $V \%$ & $S$ & $X_{\mathrm{W}} / \sigma_{\mathrm{W}}$ & $n$ & $H \%$ & $V \%$ & $S$ & $X_{\mathrm{W}} / \sigma_{\mathrm{W}}$ & $n$ & $H \%$ & $V \%$ & $S$ \\
\hline 1998 & 4 & 44 & 6 & 0.03 & $0.90 / 0.31$ & 1 & 46 & 54 & 0.25 & $1.11 / 0.67$ & 2 & 11 & 40 & 0.80 \\
\hline 2000 & 2 & 48 & 7 & 0.04 & $0.94 / 0.33$ & 2 & 38 & 18 & 0.11 & $1.08 / 0.62$ & 3 & 14 & 74 & 1.30 \\
\hline 2004 & 3 & 73 & 5 & 0.04 & $0.93 / 0.32$ & 1 & 18 & 10 & 0.11 & $1.13 / 0.64$ & 2 & 7 & 85 & 2.10 \\
\hline 2005 & 3 & 74 & 9 & 0.04 & $0.92 / 0.31$ & 1 & 13 & 6 & 0.14 & $1.15 / 0.66$ & 4 & 13 & 85 & 2.50 \\
\hline 2008 & 2 & 68 & 6 & 0.04 & $0.96 / 0.33$ & 2 & 24 & 16 & 0.30 & $1.17 / 0.66$ & 2 & 9 & 78 & 4.08 \\
\hline
\end{tabular}

Although the number of LG and $\mathrm{KZ}$ reaches is broadly similar for the surveys between 1998 and 2008, the KZs progressively became steeper and are located at positions closer to channel entrance point (Fig. 3, Table 1). Simultaneously, average channel slope increased from 0.20 to $0.44 \mathrm{~m} \mathrm{~m}^{-1}$. From 1998 until 2005, average step height increased and step density reduced, suggesting that larger steps incorporate smaller steps by incising upstream at a faster rate. The most striking change observed between 1998 and 2008 was the entrance to the englacial system, which changed from sub-horizontal to near vertical (Fig. 3). By 2008, the entrance exhibited an archetypal moulin form descending vertically $37 \mathrm{~m}$ from the contemporary surface, with the downstream conduit profile broadly characterised by a few very large steps, interspersed by many small convexities $(<1 \mathrm{~m}$ step height). This profile form remained, as revealed in the 2014 resurvey, and the evolution is reflected in the records of average step height, which more than doubled from 1998 to 2005. However, a small decline was observed between 2005 and 2008, despite the largest single step by far being evident in 2008 (Table 1).

\subsection{Knickpoint morphology}

Although observed channel knickpoints exhibit large morphological variations that are difficult to place into discrete categories, we suggest that knickpoint morphology can be divided into three major types based on the morphology at the knickpoint lip, the step riser, and the presence, size and shape of appurtenant downstream pools and conduit void spaces (Fig. 1). A similar approach to describing knickpoints has been presented by Carling et al. (2005). Here, enlarged conduit void spaces (or englacial caves) are often associated with step-riser and pool sequences or channel knickzones. The two dominant knickpoint morphologies can be considered to be end-point members of a continuum, where type 1 is characterised by a gradual transition from the upstream low gradient channel to the step riser face (Fig. 1); this morphology is similar to the break in gradient knickpoint type suggested by Haviv et al. (2010). For these knickpoints, series of longitudinal grooves parallel to the channel bed are commonly observed, and these features extend from proximate to the knickpoint lip, throughout the step riser, and in certain instances, to the downstream pool (Figs. 4c, 5). This knickpoint type may be further subdivided into two types based on the shape of the downstream pool. The first, type $1 \mathrm{~A}$, is characterised by highly elongated pools downstream of the step riser, and was observed to be most pronounced where the step riser had a relatively shallow slope. The second, type $1 \mathrm{~B}$, is where the step riser is steep, approaching a vertical nature, with the downstream pool potentially exhibiting a nearcircular plan-form geometry, with a well-developed associated englacial cave. For very large risers of this type, cave dimensions can attain diameters more than 10 times the downstream channel width. In 2000 , the cave found downstream of the vertical step extending from $\sim 40$ to $65 \mathrm{~m}$ depth, was estimated to have a volume of $\sim 400 \mathrm{~m}^{3}$ (Vatne and Refsnes, 2003). At the other end of the continuum, type 2 knickpoints are characterised by a sharp knickpoint lip and a vertical stepriser face, classified as break in elevation knickpoints (or vertical knickpoints) by Haviv et al. (2010). Type 2 knickpoints are almost exclusively found where a pool is located immediately upstream of the knickpoint, and is often observed to exist in series with two or more step pools without intervening reaches (Fig. 1). For these type 2 cases, wall grooves are absent, and characteristic channel width is often not clearly determinable. The associated downstream pools have nearcircular shapes and widths more than 3 times the average channel width found in proximate upstream and downstream LG and/or MG reaches (Fig. 4d). As all these types of knickpoints appear to incise and migrate upstream, downstream caves and pools are left remnant, resulting in channel segments exhibiting highly variable channel width, with undulating walls and channel floors (Fig. 4c, d).

\subsection{Planform changes}

In all surveys, channel incision was observed to broadly follow the pattern of the old channel, with the largest deviations coinciding with upstream migration of knickpoints. Observa- 


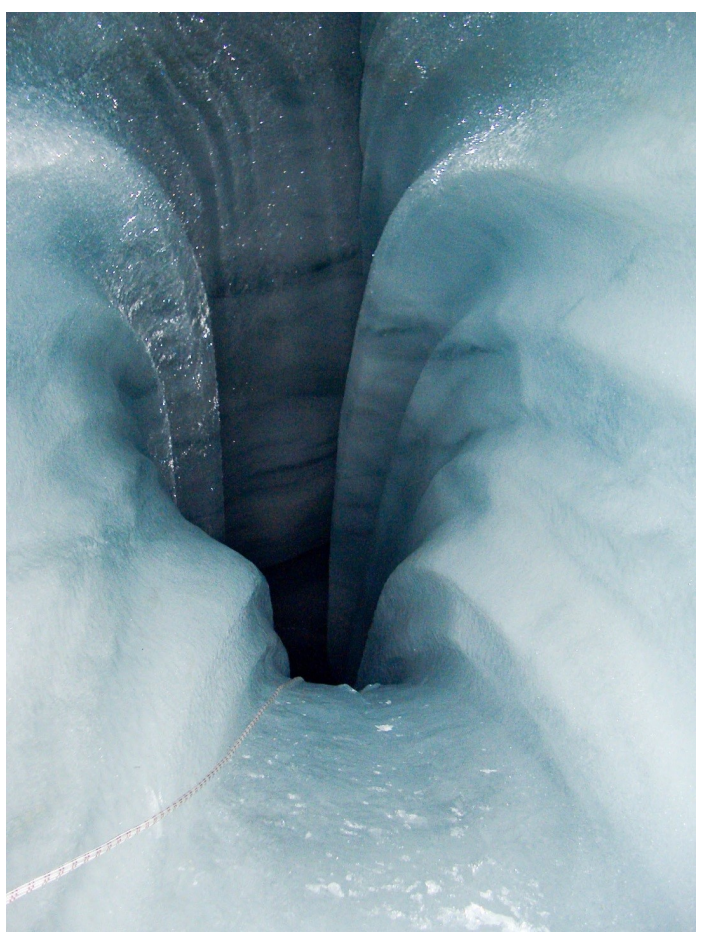

Figure 5. Grooved channel wall morphology over a knickpoint lip in 2005. Flow direction is away from the photographer. See climbing rope for scale.

tions of near-parallel channel walls extending for more than $10 \mathrm{~m}$ in LG sections confirmed more or less vertical incision (Fig. 4a). The recorded changes in planform profile mainly manifested as variations in channel curvature, resulting in a maintained overall conduit sinuosity. Meander bend migration is apparent, for example at $\sim 50 \mathrm{~m}$ horizontal distance from the entrance, but rates of development were slow compared to channel incision rates (cf. Figs. 4, 6). However, the repeat surveys do not suggest that significant lateral channel meandering was dominant; vertical incision and knickzone recession appear the prominent drivers of morphological adjustment. As noted above, incision and headward knickpoint step-riser migration is likely to mask the nature of changes in channel planform adjustment. Uncertainties in manual compass readings for individual reach bearings are likely to be responsible for slight deviations in the general directional trend of the surveyed channel (Fig. 6) and variations in channel curvature and sinuosity (ranging from 2.0 and 2.3) between the individual surveys.

\section{Discussion}

\subsection{Overview of morphological channel change}

The 10 years of repeated englacial conduit surveys at Austre Brøggerbreen show that the studied channel was sub-

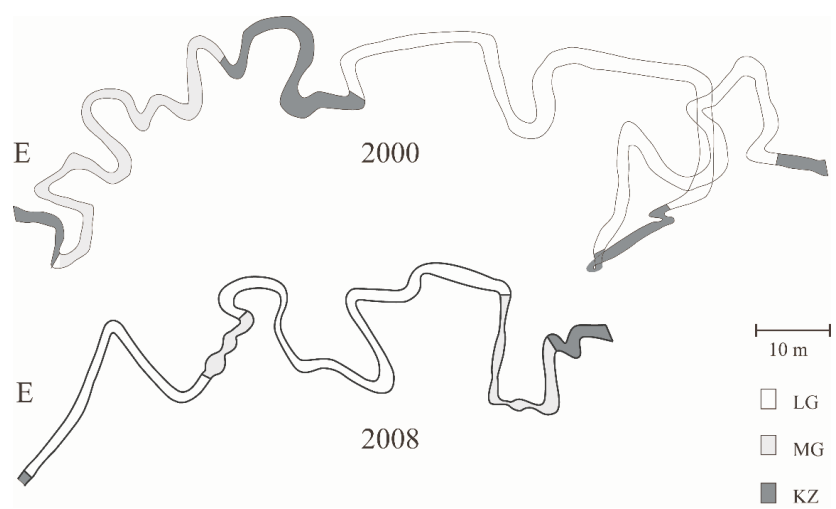

Figure 6. Schematics of englacial channel planform for 2000 and 2008, shaded to indicate the proportions of the channel classed as low gradient (LG), medium gradient (MG), and knickzone (KZ). E denotes the entrance to the channel.

ject to progressive change. The conduit geometry is not one that is clearly controlled by glacier-scale hydraulic potential (Shreve, 1972), but rather conforms to observations of sub-horizontal, stepped channels made through speleological investigations at numerous glaciers (Griselin, 1992; Gulley, 2009; Gulley et al., 2009b; Holmlund, 1988; e.g. Pulina, 1984; Vatne, 2001). The channel maintained the same overarching orientation, exhibiting minor variations in overall sinuosity. This planform change contrasts observations from Werenskioldbreen, a more dynamic polythermal glacier in Svalbard, which revealed increasing sinuosity and downstream planform elongation of a low gradient englacial channel without a markedly stepped profile (Pulina, 1984). Here, the average slope gradient of the conduit increases systematically over the study period, and the initially gently sloping englacial conduit entrance evolved to a vertical moulin form. This progression resulted in the channel evolving towards an "L-shaped" profile geometry similar to that previously reported for another englacial channel on Austre Brøggerbreen (see Stuart et al., 2003). Crucially, such morphological development challenges the prevailing assumption that crevassing (e.g. Iken, 1972; Stenborg, 1968) or hydraulic fracture (e.g. Boon and Sharp, 2003; Stenborg, 1968) is necessary for moulin development.

The changing profile shown in Fig. 3 is analogous to that of the Holocene bedrock channel profile development reported by Baynes et al. (2015) for the Jökulsárgljúfur canyon, Iceland, albeit over markedly differing timescales. This morphological development is comparable with the wave train model of stepped terrestrial channels (Loget and Van Den Driessche, 2009). Englacial step risers were rarely observed to be undercut and overhanging, suggesting that undercutting is an insignificant process in englacial step evolution and migration, similar to what is observed for many bedrock waterfalls (Lamb et al., 2007; Young, 1985). While glacial streams are mechanistically different from bedrock channels, 
processes may be equivalent: roles of bedload (e.g. Cook et al., 2013; Sklar and Dietrich, 2001) and bedrock strength (e.g. Jansen, 2006) are replaced with thermal erosion and the structure and crystallography of the ice substrate.

For the englacial conduit reported here, potential extrinsic influences from (i) extra-channel clastic supply, (ii) fundamental substrate structure, (iii) flood events, or (iv) periodic increases in contributing drainage area are largely absent. Supraglacial stream water is typically free of a sediment load, other than instances of heightened concentrations of fine (silt and clay fraction) suspended sediment, associated with debris mobilised to the glacier surface from the ice margin (Porter et al., 2010). Although no systematic study of ice structure was undertaken during the surveys, no evidence for structural controls on drainage morphology (e.g. Benn et al., 2009; Gulley, 2009; Gulley and Benn, 2007; Hambrey, 1977) were observed, despite continuous scrutiny of the channel boundaries. As Jennings et al. (2015) reported from observations of the glacier surface, locally the glacier exhibits a remarkably low density of ice structures likely to influence the drainage system. The elevation of the conduit outlet at the glacier margin remained broadly constant, meaning that only changes in local (reach-scale) base level could have influenced channel adjustment. Trends in summer melt production and duration did not occur over the study period (Nowak and Hodson, 2013). During the summer, meltwater production on Austre Brøggerbreen is typically characterised initially by snowmelt and delayed flow that transitions to increasing melt volumes as the snow cover declines, and as seasonal patterns and diurnal variability of incident radiation and air temperature dominate the melt process (Hodson et al., 1998); diurnally fluctuating discharges decline as the summer season closes. Heightened ("flood") discharges can result from synoptic forcing and/or rainfall events, but the hydrological effect can be complex, and summer season precipitation in the locality is low (Førland et al., 2011; Hodson et al., 1998). Combined, these conditions suggest that the flow regime through the surveyed conduit section, although varied, is smoothed and moderately stable at sub-seasonal to annual timescales, when compared to terrestrial channels. The contributing area above the channel entrance may change as a result of alterations in surface topography caused by melt; however, annual surface lowering at Austre Brøggerbreen is broadly consistent with a clear elevation dependency at elevations above $\sim 200 \mathrm{~m}$ a.s.l. (Barrand et al., 2010). No tributary englacial channels were observed to merge with the surveyed conduit. Accordingly, it is assumed the drainage area delivering meltwater to the channel remains constant over our observation period.

In the absence of clear extrinsic controls, comparisons between bedrock and ice-bounded channels may be drawn, but with a primary focus on intrinsic, hydraulic processes. Our contention is that hydraulically driven $\mathrm{KZ}$ recession, coupled with progressive albeit slow vertical incision, dominates englacial channel adjustment, thereby minimising and con- cealing the nature of any meander bend migration and development over the study period. This notion is reaffirmed by observations made in LG reaches, where the former conduit floor could be discerned at heights above the contemporary channel floor (Fig. 4a, b), akin to strath terraces; such perched meander bends have been observed in other englacial channels (e.g. Gulley et al., 2009a). Moreover, during the study period, there was no evidence of englacial channel re-routing due to conduit blockage (Griselin, 1992; Gulley et al., 2009a). Therefore, the remaining discussion focuses on morphological characteristics of the different reaches and variations therein, exploring potential controls in step-riser morphology and their relation to upstream knickzone migration rates and conduit maintenance.

\subsection{Do englacial conduits exhibit time-invariant morphological characteristics?}

Knighton (1985) suggested that supraglacial streams are capable of developing and maintaining characteristic forms. Here, our analysis and classification of the longitudinal channel profiles imply that primary reach morphologies also exist and persist in annually reoccupied cut-and-closure englacial conduits. The LG, MG, and KP reach forms have contrasting rates of channel adjustment, which in turn conditions the overall morphology of the englacial flow path, and results in a time-variant, evolving channel.

The LG reaches constitute the major reach type for conveying water horizontally, representing on average about $62 \%$ of the horizontal channel length. This type of reach has uniform morphology and consistent channel gradients, both within and between individual surveys. They are observed to incise with near-constant cross-sectional form, in line with observations in supraglacial streams (Marston, 1983). Therefore, commonly, LG englacial channels walls are comparatively parallel, only containing gentle undulations. This form suggests conditions of reduced friction and low heat dissipation, thus resulting in low channel incision rates in comparison with adjacent $\mathrm{MG}$ or $\mathrm{KZ}$ reaches.

MG reaches show the highest variability with respect to percentage of descent and horizontal channel length, both within and between surveys (Table 2), and are associated with planform meandering and lateral incision (Fig. 4b) leading to highly variable channel widths. Meandering is commonly observed in supraglacial environments over a range of channel slopes (Dozier, 1976; Ferguson, 1973; Knighton, 1972). Driven by helical flow, incoming flow creates a transverse bed slope, which in turn creates a curvature and topography-driven secondary flow (Blanckaert and De Vriend, 2004; Chen and Tang, 2012). Such secondary currents may lead to knickpoint development as seen in supraglacial channels (Fig. 7) (Mantelli et al., 2015). Our data do not allow for quantification of the rates at which $\mathrm{MG}$ reaches develop or evolve; therefore, we interpret the varying importance of $\mathrm{MG}$ reaches in the observed conduits to 
represent an unstable reach type that progresses toward a $\mathrm{KZ}$ geometry.

Found in all surveys, KZ reaches appear to be a typical and recurrent channel form. The data presented here show that the KZs adopt increasing steepness (Table 1), which is a result of a general increase in step-riser height, and an increasing proportion of the conduit's vertical descent taking place through the $\mathrm{KZ}$ reaches. The influence of increasing water temperatures as potential energy is lost in descending through knickzones (Isenko, 2006) may aid this subtle change in KZ form. However, akin to bedrock channels, the manner in which KZs adjust over time is likely related to the specific form(s) of the step sequence, and the proportion of flow that is bed-supported or a ballistic jet (e.g. Carling et al., 2005). We suggest that, once formed, KZs are self-reinforcing features as they sustain higher heat dissipation and incision rates than low or medium gradient channel reaches situated immediately upstream and downstream. However, the KZ reaches are unlikely to incise vertically beyond the base of their associated plunge pool, as they are constrained by the nature of heat dissipation and downstream LG channels, which serves as a local base level.

While characteristic reach types were found in all surveys, the morphology was continually changing. This is thus suggestive of an englacial system in the process of rapid, transient development (particularly prior to 2005), through which evolution of KZs and $\mathrm{KZ}$ recession, lead to a single, high step riser (moulin), and LG englacial reaches that are controlled by the drainage system base level.

\subsection{Conceptual model of factors controlling knickpoint face gradient and channel evolution}

Vatne and Refsnes (2003) suggest that large step risers retreat at a faster rate than smaller risers, with hydrodynamic theory predicting heightened melt rates at high and steep risers (Isenko and Mavluydov, 2002). However, these notions are challenged by the data presented here; the evolution of the KZ reaches shows no simple relation between stepriser/knickzone height and knickpoint/knickzone recession rate (Fig. 3). To resolve this apparent absence of a direct relationship, we propose a conceptual model of process-form linkages, whereby knickpoint lip shape, which controls the type of jet that forms, influences knickpoint recession rate, by determining the amount of direct heat transfer to the stepriser face. This conforms to conceptual models of bedrock step-pool sequence evolution (Carling et al., 2005) and channel downcutting, which are dominated by wave trains of knickzone migration upstream (Loget and Van Den Driessche, 2009).

The progressive evolution of the englacial conduit at Austre Brøggerbreen (Fig. 3) appears to be dominated by $\mathrm{KZ}$ reaches that, over time, have evolved from MG into KZ morphology. The KZs have subsequently receded headward, and ultimately reached the channel entrance location. Arguments

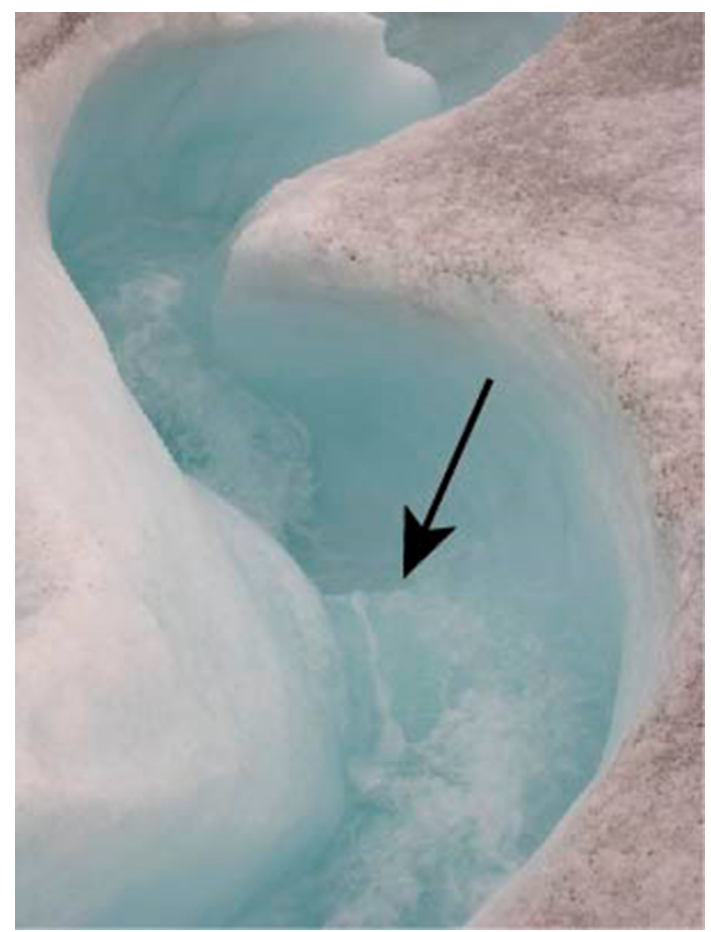

Figure 7. Development of a knickpoint in a supraglacial meander bend at Austre Brøggerbreen, August 2007. Flow direction is away from the photographer. Channel width is approximately $40 \mathrm{~cm}$ at the knickpoint.

supporting a transition from $\mathrm{MG}$ to $\mathrm{KZ}$ reaches can be found both in the observed evolution of the conduit profile, observations in supraglacial streams, and studies of flow and secondary currents in meander bends. As a knickzone recedes laterally upstream it will leave behind a gently sloping channel reach, which retains its fundamental channel characteristics until it is captured by the next downstream knickzone incising upstream. This process of channel evolution has been previously implied (Gulley et al., 2009a), but is yet to be clearly demonstrated. Here, at Austre Brøggerbreen, it is likely that the same KZs are observed from one survey to the next, albeit with migration to an upstream location, as headward incision of knickpoints outpaces vertical incision through low gradient reaches.

For an ice walled channel, incision rates will mainly be controlled by heat produced a few channel diameters upstream, as heat is rapidly lost to the surrounding ice (Isenko et al., 2005). Therefore, incision rates are correlated with water velocity (Lock, 1990) and rate of heat loss to the channel boundaries (Jarosch and Gudmundsson, 2012). This is observed for the channel segments immediately upstream of type 1 knickpoints (Fig. 1), where grooves demonstrate a strong resemblance to morphologies reported for progressive incision for supraglacial streams at diurnal timescales (Marston, 1983). The grooves provide evidence for amplified incision over the knickpoint lip, as the channel-bed gra- 
dient increases. Analogies in bedrock channels are found immediately above steps (Richardson et al., 2005) and for which groove spacing may relate to formative discharge (e.g. Ikeda, 1978). Here, the grooves may represent morphological markers representing high, dominant or recurrent discharge regimes; however, the drivers and timescales of groove formation remains unclear. Nevertheless, it is possible that such features could be used as a proxy from which to reconstruct incision rates for channel reaches of differing gradient.

The grooves found along type 1A knickpoints (Fig. 1) attest to the presence of a dominantly bed-supported jet: heat is lost along the entire step riser, and recession rates will be highest on the downstream end. The typically elongated downstream pools associated with type 1A knickpoints suggest that much of the momentum, and thus heat, is transferred and dissipated throughout the pool in a downstream direction. Limited heat is dissipated laterally, constraining channel width. We, therefore, suggest that type 1A knickpoints effectively transfer heat to the channel bed at the lower end of the step riser, steepening the step, and thus enabling the highest headward recession rates of all the observed knickpoint types.

Step risers of type 1B only demonstrate grooves in the upper part of the step riser, and exhibit associated cave forms, both of which suggest that water flow detaches from the riser face and becomes ballistic (Fig. 1). Consequently, only a portion of the heat energy is dissipated over the channel bed, if at all, and the headward recession rates are subdued compared to type 1A knickpoints. The ballistic jet may be subject to break-up in the air (Chanson, 1994) and the resulting spray could play an important role in energy dissipation and heat transfer to the ice cave walls. Cave size will be influenced by discharge, flow velocity and step-riser height that, combined, control the degree of flow detachment and jet breakup and impact point. Dimensions of these caves are likely mediated by energy dissipation and ice creep closure; this quasi-equilibrium form may be analogous to that suggested in flume studies and theoretical considerations for bedrock rivers (Mason and Arumugam, 1985; Stein et al., 1993), where jet impact angle, jet velocity, and the tailwater depth are influential (Pagliara and Hager, 2006). A combination of a partly bed-supported and partly ballistic jet at a type 1B knickpoint may lead to higher recession rates in the upper part of the riser face, allowing transition towards type 1A morphology. During low flows, a lesser degree of detachment will erode the step riser, as suggested for type 2 knickpoints and evidenced by narrow furrows incised into the step riser face at under low-flow conditions (Fig. 8); this process is also seen for bedrock channel settings (Carling et al., 2005).

At the base of step risers, jet impact causes a submerged hydraulic jump and immediate heat dissipation within the pools themselves. Exit channels from these caves are typically near horizontal, and rapidly attain a cross-sectional area similar to that found immediately upstream of the knickpoint. This suggests that most of the heat is dissipated locally within

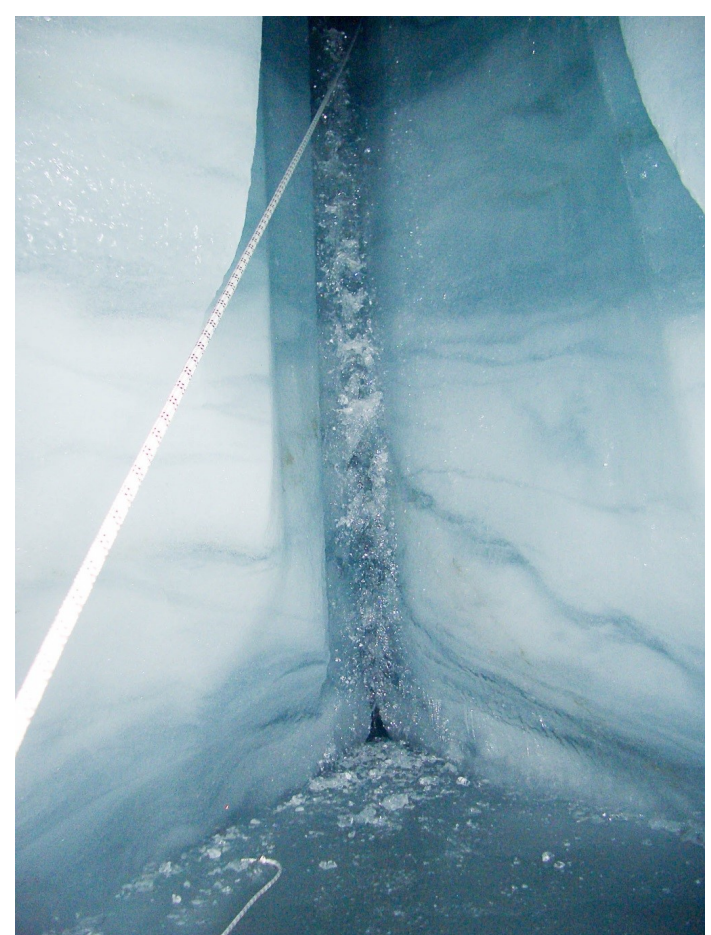

Figure 8. Step riser with narrow furrow incised during low discharge at the end of the ablation season. Flow direction is towards the photographer.

the plunge pool and cave, as water rapidly attains equilibrium temperature (Isenko et al., 2005), and secondary circulation currents (Venditti et al., 2014) rapidly reduce the excess heat energy.

Type 2 knickpoints are typically found within sequences of step pools with no intervening straight low gradient conduit (Fig. 4d). Here, these step risers were more or less vertical, suggesting the shape of the step riser retains an equilibrium longitudinal profile where the flow is in contact face. However, this type of knickpoint also forms associated caves, but typically with lower englacial void volumes than type 1B caves. Here, it is the lateral recession of the step riser that produces the more canyon-like cave form. Although KZ height development is influenced by the incision rate of the downstream LG reach, it will also be influenced by the gradient of the upstream reach it captures through headward erosion, and the rate in which it does so.

Our results highlight that $\mathrm{KZ}$ recession rates are an order of magnitude higher than vertical incision of low gradient reaches. This observation is in line with observations both in ice-walled conduits (e.g. Gulley et al., 2009a) and in bedrock channels (Hayakawa and Matsukura, 2003; Turowski et al., 2009). Vatne and Refsnes (2003) measured incision rates of $1-1.8 \mathrm{ma}^{-1}$ in $\mathrm{LG}$ reaches between two consecutive surveys. Although these rates are lower than those observed in supraglacial streams (Dozier, 1976; Marston, 1983; Müller, 2007), this is unsurprising. (i) The typical gra- 
dient in $\mathrm{LG}$ reaches reported here $\left(0.04 \mathrm{~m} \mathrm{~m}^{-1}\right)$ is lower than that reported in the literature for supraglacial streams, and (ii) the meltwater in the englacial channel is isolated from the meteoric energy contributions that can contribute to heat in supraglacial streams, and which may account for $25-50 \%$ of the incision rate (Dozier, 1976; Stock and Pinchak, 1995). The LG reaches seem to largely inherit the planform geometry left behind by the upstream $\mathrm{KZ}$ recession that forms them; hence, it is unclear if, over time, meandering can develop in LG reaches. Knickzones appear to adopt and adapt the existing upstream planform geometry, and simultaneously appear to reduce channel sinuosity.

\subsection{Perennial conduit persistence and morphological maintenance}

The persistence of the conduit itself is of interest, with clear evidence that the mapped conduit is reoccupied each melt season. The closure rate $(\partial r / \partial t)$ for a circular conduit can be approximated following Nye (1953) and Röthlisberger and Lang (1987):

$$
\frac{\partial r}{\partial t}=-r A\left(\frac{\rho_{\mathrm{i}} g h_{\mathrm{i}}}{n}\right)^{n},
$$

where $p_{\mathrm{i}}$ is glacier ice density, $g$ is gravitational acceleration, $h_{\mathrm{i}}$ is overlying ice thickness, and $r$ the conduit radius. The remaining terms are ice flow parameters: $n$ is the ice creep parameter $(\approx 3)$, and $A$ is ice temperature dependent. Equation (2) can be solved for $r$ as a function of the original conduit radius $\left(r_{0}\right)$ and time $(t)$ :

$r_{t}=r_{0} e^{-A\left(\frac{\rho_{\mathrm{i}} g h_{\mathrm{i}}}{n}\right)^{n} t}$.

Using the published ice temperature profile from Austre Brøggerbreen's ablation area (Hagen et al., 1991), and the non-linear relationship between ice temperature and $A$ (see Cuffey and Paterson, 2010: Table 3.4), theoretical conduit closure over winter was estimated for a circular channel cross section. Figure 9a illustrates the percentage closure rates for an englacial conduit within Austre Brøggerbreen over time since the end of the hydraulically active melt season, assuming a 70-day long summer season commencing in June, as is typical at the study site (Hodson et al., 2000; Nowak and Hodson, 2013). Channels remain open with minimal closure in the uppermost $40 \mathrm{~m}$ of the glacier. However, conduits at depths of greater than $\sim 75 \mathrm{~m}$ will exhibit closure of $50 \%$ or more over the course of the winter months. These results correspond to numerical simulations of incising englacial channels that lead to the formation of deep, narrow conduits exhibiting open-channel flow (e.g. Jarosch and Gudmundsson, 2012). The contrasts in the rate of channel closure are highlighted when considering the theoretical conduit diameters to be expected in the October and April surveys reported here, assuming a $1 \mathrm{~m}$ diameter conduit at the close of the melt season. These channel closure data contradict our field observa-
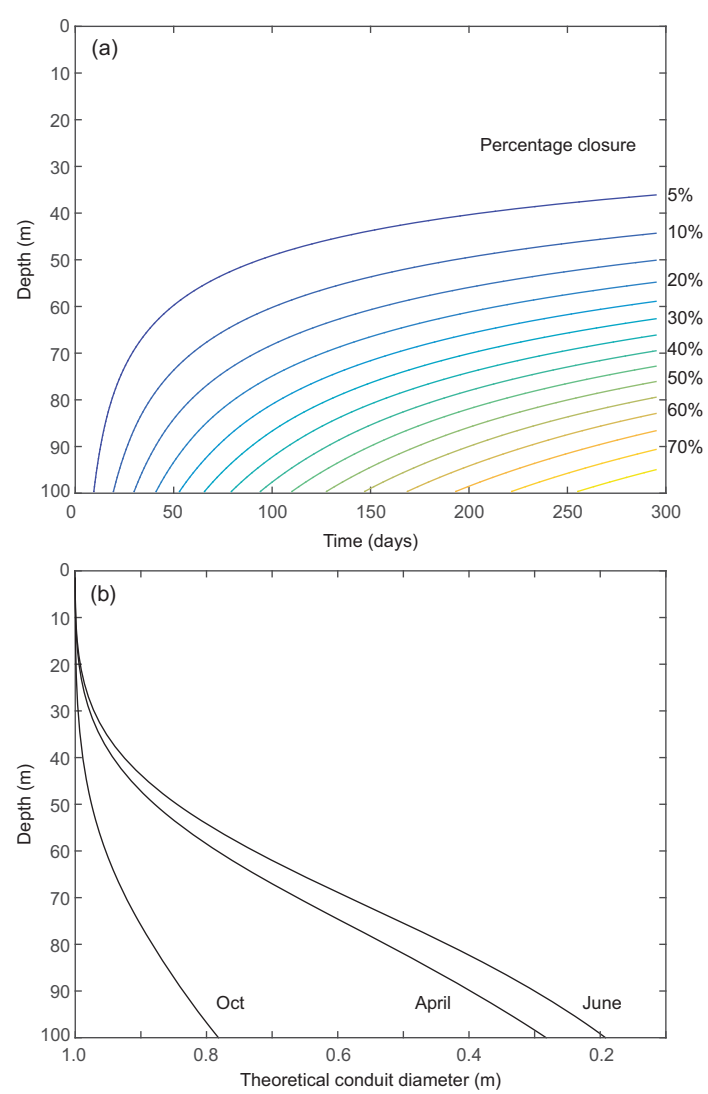

Figure 9. (a) Contour plot of the theoretical percentage closure for a hydrologically inactive englacial channel within Austre Brøggerbreen over time; (b) illustration of the theoretical channel dimensions for the englacial conduit assuming a $1 \mathrm{~m}$ diameter at the end of the hydrologically active season (September) for the October and April survey dates, and for the resumption of the melt season (June).

tions from autumn and spring campaigns that show a consistent mean and variance in channel diameter across the five surveys (Table 2), together with evidence of the conduit remaining open to depths of $85 \mathrm{~m}$ (e.g. in 2008). Open-channel water-free conduits of similar dimensions have also been observed elsewhere at depths greater than $70 \mathrm{~m}$ (see Table 2 in Gulley et al., 2009b).

While deeper parts of the surveyed conduit did show signs of creep closure, the consistency and persistence of channel geometries reported here highlight the need to better constrain the nature of englacial channel closure and processes contributing to channel maintenance. Commonly, the persistence of englacial and subglacial channels at depth is ascribed to a reduction in conduit closure rate through water storage (e.g. Benn et al., 2009; Irvine-Fynn et al., 2011; Schroeder, 2007). As detailed in Sect. 3.2, the exploration of the englacial channel at Austre Brøggerbreen was halted due to unfrozen pools or water-filled conduit segments, at depths greater than $60 \mathrm{~m}$. It is possible that the surveyed conduit was periodically water filled during the winter months 
between the surveys. However, over the last 2 decades, Austre Brøggerbreen has never formed a proglacial icing, which suggests winter drainage and periodic emptying of waterfilled englacial conduits does not take place here, contrary to observations at many other cold glaciers in Svalbard (e.g. Hodgkins et al., 1998). Consequently, the role of over-winter water storage in maintaining the conduit geometries at depths greater than $50 \mathrm{~m}$ is unclear.

With recognition that englacial channel incision may be significant for meltwater flow paths in valley glaciers (Gulley et al., 2009a; Naegeli et al., 2014), ice caps and the Greenland Ice Sheet (Ahlstrøm, 2007; Andrews et al., 2014; Catania et al., 2008; McGrath et al., 2011; Reynaud and Moreau, 1994), it is vital to further refine the process mechanics of englacial conduit behaviour (e.g. Evatt, 2015). The combined approach of speleological investigations of englacial cave morphology, coupled with numerical models to simulate conduit change, may serve to clarify channel forming processes.

\section{Conclusions}

This research presents a unique time series of morphological observations of an englacial channel in a cold-based glacier, and provides new insights into dynamic channel adjustment and processes controlling conduit evolution, providing the basis for a conceptual model of process - form linkages of step-riser geometry. We found that englacial channels develop and maintain characteristic channel reaches, namely low gradient, medium gradient, and knickzone reaches. The consistencies in channel form over the survey period suggest these channel-reach types can be considered time-invariant equilibrium morphological features. Knickzones are responsible for the majority of the geomorphic work, as recession rates are a magnitude higher in knickzones than vertical incision in low gradient reaches. Knickpoint lip shape controls the type of jet produced, either bed supported, ballistic, or a combination, which in turn controls knickpoint headward recession rates. We argue that bed-supported jets are more efficient in transferring heat to the channel bed compared to ballistic jets; hence, they are responsible for higher recession rates. However, ballistic jets can contribute to the development of englacial caves associated with knickzones, through aiding melt processes at the ice walls. The multiple surveys reported here demonstrate that deep vertical moulins may be formed by the incision of supraglacial streams, in combination with headward recession of knickzones. This morphological development coupled with the apparent deficiencies in being able to model conduit closure rates successfully highlight the importance of continuing research in englacial hydrological behaviour.

Acknowledgements. The authors acknowledge Aslak Aastorp (1998), Ingeborg Refsnes (2000), Stian Aune (2004), Bjarne Bergheim (2005), and Jaran Wasrud (2008), who assisted GV in the surveys of the channels, and Sille Myreng for providing data for 2014. Fieldwork has been supported by Svalbard Science Forum through several Arctic Field grants. TDLI-F acknowledges support from the Climate Change Consortium of Wales (C3W). Helpful and insightful comments from Stephen Tooth and Hywel Griffiths were gratefully received, as were inputs from Ian Stevens, Jayne Kamintzis, and Stephen Jennings.

Edited by: B. Schaefli

\section{References}

Abrahams, A. D., Li, G., and Atkinson, J. F.: Step-pool streams: Adjustments to maximum flow resistance, Water Resour. Res., 31, 2593-2602, 1995.

Ahlstrøm, A. P.: Previous glaciological activities related to hydropower at Paakitsoq, Ilulissat, West Greenland, Geol. Surv. Den. Greenl., Copenhagen, 43 pp., 2007.

Andrews, L. C., Catania, G. A., Hoffman, M. J., Gulley, J. D., Luthi, M. P., Ryser, C., Hawley, R. L., and Neumann, T. A.: Direct observations of evolving subglacial drainage beneath the Greenland Ice Sheet, Nature, 514, 80-83, doi:10.1038/nature13796, 2014.

Ashida, K., Takahashi, T., and Sawada, T.: Sediment yield and transport on a mountainous small watershed, Bulletin of the Disaster Prevention Research Institute, 26, 119-144, 1976.

Bælum, K. and Benn, D. I.: Thermal structure and drainage system of a small valley glacier (Tellbreen, Svalbard), investigated by ground penetrating radar, The Cryosphere, 5, 139-149, doi:10.5194/tc-5-139-2011, 2011.

Barrand, N. E., James, T. D., and Murray, T.: Spatiotemporal variability in elevation changes of two high-Arctic valley glaciers, J. Glaciol., 56, 771-780, 2010.

Baynes, E. R. C., Attal, M., Niedermann, S., Kirstein, L. A., Dugmore, A. J., and Naylor, M.: Erosion during extreme flood events dominates Holocene canyon evolution in northeast Iceland, P. Natl. Acad. Sci. USA, 112, 2355-2360, doi:10.1073/pnas.1415443112, 2015.

Benn, D., Gulley, J., Luckman, A., Adamek, A., and Glowacki, P. S.: Englacial drainage system formed by hydrologically driven crevasse propoagation, J. Glaciol., 55, 513-523, 2009.

Bishop, P., Hoey, T. B., Jansen, J. D., and Artza, I. L.: Knickpoint recession rate and catchment area: the case of uplifted rivers in Eastern Scotland, Earth Surf. Proc. Land, 30, 767-778, doi:10.1002/esp.1191, 2005.

Björnsson, H., Gjessing, Y., Hamran, S.-E., Hagen, J. O., Liestø1, O., Pálsson, F., and Erlingsson, B.: The thermal regime of subpolar glaciers mapped by multi-frequency radio-echo sounding, J. Glaciol., 42, 23-32, 1996.

Blanckaert, K. and De Vriend, H. J.: Secondary flow in sharp open-channel bends, J. Fluid Mech., 498, 353-380, doi:10.1017/S0022112003006979, 2004.

Boon, S. and Sharp, M.: The role of hydrologically-driven ice fracture in drainage system evolution on an Arctic glacier, Geophys. Res. Lett., 30, 1916, doi:10.1029/2003g1018034, 2003.

Brykała, D.: Short-term changes of flow intensity and hydraulic geometry of the supraglacial stream on Waldemar Glacier (NW Spitsbergen). Quaternary Paleogeography and Changes of the Polar Environment: Spitsbergen Geographical Expedition: IV 
Conference of Polish Geomorphologists, Lublin, Poland., 25-39, 1998.

Carling, P. A., Tych, W., and Richardson, K.: The hydraulic scaling of step-pool systems, in: River, coastal and estuarine morphodynamics, edited by: Parker, G. and Garcia, M. H., Taylor \& Francis, New York, 2005.

Carver, S., Sear, D., and Valentine, E.: An observation of roll waves in a supraglacial meltwater channel, Harlech Gletscher, East Greenland, J. Glaciol., 40, 75-78, 1994.

Castillo, M., Bishop, P., and Jansen, J. D.: Knickpoint retreat and transient bedrock channel morphology triggered by baselevel fall in small bedrock river catchments: The case of the Isle of Jura, Scotland, Geomorphology, 180-181, 1-9, doi:10.1016/j.geomorph.2012.08.023, 2013.

Catania, G. A., Neumann, T. A., and Price, S. F.: Characterizing englacial drainage in the ablation zone of the Greenland ice sheet, J. Glaciol., 54, 567-578, doi:10.3189/002214308786570854, 2008.

Chanson, H.: Comparison of energy dissipation between nappe and skimming flow regimes on stepped chutes, J. Hydraul. Res., 32, 213-218, 1994

Chartrand, S. M. and Whiting, P. J.: Alluvial architecture in headwater streams with special emphasis on step-pool topography, Earth Surf. Proc. Land., 25, 583-600, 2000.

Chen, D. and Tang, C.: Evaluating secondary flows in the evolution of sine-generated meanders, Geomorphology, 163-164, 37-44, doi:10.1016/j.geomorph.2012.04.010, 2012.

Chin, A.: Step pools in stream channels, Prog. Phys. Geog., 13, 391-408, 1989.

Chin, A.: On the stability of step-pool mountain streams, J. Geol., 106, 59-70, doi:10.1086/516007, 1998.

Chin, A.: The period nature of step-pool mountain streams, Am. J. Sci., 302, 144-167, 2002.

Chin, A.: The geomorphic significance of step-pools in mountain streams, Geomorphology, 55, 125-137, 2003.

Chin, A. and Phillips, J. D.: The self-organization of step-pools in mountain streams, Geomorphology, 83, 346-358, 2007.

Chin, A. and Wohl, E.: Toward a theory for step pools in stream channels, Prog. Phys. Geog., 29, 275-296, 2005.

Church, M.: Geomorphic thresholds in riverine landscapes, Freshwater Biol., 47, 541-557, 2002.

Church, M. and Zimmermann, A.: Form and stability of step-pool channels: Research progress, Water Resour. Res., 43, W03415, doi:10.1029/2006wr005037, 2007.

Clayton, L.: Karst topography on stagnant glaciers, J. Glaciol., 5, 107-112, 1964.

Comiti, F., Cadol, D., and Wohl, E.: Flow regimes, bed morphology, and flow resistance in self-formed step-pool channels, Water Resour. Res., 45, W04424, doi:10.1029/2008WR007259, 2009.

Cook, K. L., Turowski, J. M., and Hovius, N.: A demonstration of the importance of bedload transport for fluvial bedrock erosion and knickpoint propagation, Earth Surf. Proc. Land., 38, 683695, doi:10.1002/esp.3313, 2013.

Crosby, B. T. and Whipple, K. X.: Knickpoint initiation and distribution within fluvial networks: 236 waterfalls in the Waipaoa River, North Island, New Zealand, Geomorphology, 82, 16-38, doi:10.1016/j.geomorph.2005.08.023, 2006.

Cuffey, K. M. and Paterson, W. M.: The physics of glaciers, Elsevier, Oxford, 2010.
Curran, J. H. and Wohl, E. E.: Large woody debris and flow resistance in step-pool channels, Cascade Range, Washington, Geomorphology, 51, 141-157, doi:10.1016/s0169-555x(02)00333-1, 2003.

Davis, W. M.: Piedmont benchlands and primarrumpfle, Geol. Soc. Am. Bull., 43, 399-440, 1932.

Dozier, J.: Channel adjustments in supraglacial streams, Icefield Ranges Research Project, American Geographical Society, Scientific Results, 4, 189-205, 1974.

Dozier, J.: Examination of Variance Minimization Tendencies of a Supra-Glacial Stream, J. Hydrol., 31, 359-380, 1976.

Dust, D. and Wohl, E.: Characterization of the hydraulics at natural step crests in step-pool streams via weir flow concepts, Water Resour. Res., 48, W09542, doi:10.1029/2011WR011724, 2012.

Evatt, G. W.: Röthlisberger channels with finite ice depth and open channel flow, Ann. Glaciol., 56, 45-50, doi:10.3189/2015AoG70A992, 2015.

Ferguson, R. I.: Sinuosity of Supraglacial Streams, Geol. Soc. Am. Bull., 84, 251-255, 1973.

Førland, E. J., Benestad, R., Hanssen-Bauer, I., Haugen, J. E., and Skaugen, T. E.: Temperature and Precipitation Development at Svalbard 1900-2100, Advances in Meteorology, 2011, 893790, doi:10.1155/2011/893790, 2011.

Fountain, A. G. and Walder, J. S.: Water flow through temperate glaciers, Rev. Geophys., 36, 299-328, doi:10.1029/97RG03579, 1998.

Gardner, T. W.: Experimental study of knickpoint and longitudinal profile evolution in cohesive, homogeneous material, Geol. Soc. Am. Bull., 94, 664-672, doi:10.1130/00167606(1983)94<664:esokal>2.0.co;2, 1983.

Garmin: http://www8.garmin.com/aboutGPS/ (last access: 3 March 2015), 2015.

Grant, G. E., Swanson, F. J., and Wolman, M. G.: Pattern and origin of stepped-bed morphology in high-gradient streams, Western Cascades, Oregon, Geol. Soc. Am. Bull., 102, 340-352, doi:10.1130/0016-7606(1990)102<0340:paoosb>2.3.co;2, 1990.

Griselin, M.: In the depth of a small polar glacier (Loven East Glacier, Spitsbergen), Proceedings of the 2nd International GLACKIPR Symposium, University of Silesia, Poland, 10-16 February 1992, 51-63, 1992.

Gulley, J.: Structural control of englacial conduits in the temperate Matanuska Glacier, Alaska, USA, J. Glaciol., 55, 681-690, 2009.

Gulley, J. and Benn, D. I.: Structural control of englacial conduits in Himalayan debris-covered glaciers, J. Glaciol., 53, 399-412, 2007.

Gulley, J. D., Benn, D. I., Muller, D., and Luckman, A.: A cut-andclosure origin for englacial conduits in uncrevassed regions of polythermal glaciers, J. Glaciol., 55, 66-80, 2009a.

Gulley, J. D., Benn, D. I., Screaton, E., and Martin, J.: Mechanisms of englacial conduit formation and their implications for subglacial recharge, Quaternary Sci. Rev., 28, 1984-1999, doi:10.1016/j.quascirev.2009.04.002, 2009b.

Hagen, J. O. and Lefauconnier, B.: Reconstructed runoff from the High Arctic basin Bayelva based on mass balance measurements, Nord. Hydrol., 26, 285-296, 1995.

Hagen, J. O. and Liestøl, O.: Long term glacier mass balance investigations in Svalbard, 1950-1988, Ann. Glaciol., 14, 102-106, 1990. 
Hagen, J. O., Korsen, O. M., and Vatne, G.: Drainage pattern in a subpolar glacier: Brøggerbreen, Svalbard, in: Arctic Hydrology, Present And Future Tasks, edited by: Gjessing, Y., Hagen, J. O., Hassel, K. A., Sand, K., and Wold, B., Norwegian National Comittee of Hydrology, Oslo, 121-131, 1991.

Hambrey, M. J.: Supraglacial drainage and its relationship to structure, with particular reference of Charles Rabots Bre, Okstindan, Norway, Norsk Geogr. Tidsskr., 31, 69-77, 1977.

Hambrey, M. J.: Sudden draining of ice-dammed lakes in Spitsbergen, Polar Rec., 22, 189-194, 1984.

Haviv, I., Enzel, Y., Whipple, K. X., Zilberman, E., Matmon, A., Stone, J., and Fifield, K. L.: Evolution of vertical knickpoints (waterfalls) with resistant caprock: Insights from numerical modeling, J Geophys. Res., 115, F03028, doi:10.1029/2008JF001187, 2010.

Hayakawa, Y. and Matsukura, Y.: Recession rates of waterfalls in Boso Peninsula, Japan, and a predictive equation, Earth Surf. Proc. Land., 28, 675-684, doi:10.1002/esp.519, 2003.

Hayakawa, Y. S. and Matsukura, Y.: Stability analysis of waterfall cliff face at Niagara Falls: An implication to erosional mechanism of waterfall, Eng. Geol., 116, 178-183, doi:10.1016/j.enggeo.2010.08.004, 2010.

Hayakawa, Y. S. and Oguchi, T.: DEM-based identification of fluvial knickzones and its application to Japanese mountain rivers, Geomorphology, 78, 90-106, doi:10.1016/j.geomorph.2006.01.018, 2006.

Hayakawa, Y. S. and Oguchi, T.: GIS analysis of fluvial knickzone distribution in Japanese mountain watersheds, Geomorphology, 111, 27-37, doi:10.1016/j.geomorph.2007.11.016, 2009.

Hayakawa, Y. S. and Oguchi, T.: Spatial correspondence of knickzones and stream confluences along bedrock rivers in Japan: implications for hydraulic formation of knickzones, Geogr. Ann. A., 96, 9-19, doi:10.1111/geoa.12024, 2014.

Hodgkins, R., Tranter, M., and Dowdeswell, J. A.: The hydrochemistry of runoff from a "cold-based" glacier in the High Arctic (Scott Turnerbreen, Svalbard), Hydrol. Process., 12, 87-103, 1998.

Hodson, A., Gurnell, A., Tranter, M., Bogen, J., Hagen, J. O., and Clark, M. J.: Suspended sediment yield and transfer processes in a small High-Arctic glacier basin, Svalbard, Hydrol. Process., 12, 73-86, 1998.

Hodson, A., Tranter, M., and Vatne, G.: Contemporary rates of chemical denudation and atmospheric $\mathrm{CO} 2$ sequestration in glacier basins: an Arctic perspective, Earth Surf. Proc. Land., 25, 1447-1471, doi:10.1002/1096-9837(200012)25:13<1447::AIDESP156>3.0.CO;2-9, 2000.

Hodson, A., Tranter, M., Gurnell, A., Clark, M., and Hagen, J. O.: The hydrochemistry of Bayelva, a high Arctic proglacial stream in Svalbard, J. Hydrol., 257, 91-114, 2002.

Holland, W. N. and Pickup, G.: Flume study of knicpoint development in stratified sediment, Geol. Soc. Am. Bull, 87, 76-82, 1976.

Holmlund, P.: Internal geometry and evolution of moulins, Storglaciären, Sweeden, J. Glaciol., 34, 242-248, 1988.

Holtermann, C.: Flow conditions within englacial drainage channels. A dye tracer study from Austre Brøggerbreen, Svalbard, MS thesis, Dept. of Geography, Norwegian University of Science and Technology, Trondheim, 58 pp., 2007.
Howard, A. D.: Long profile development of bedrock channels: Interaction of weathering, mass wasting, bed erosion, and sediment transport, in: Rivers Over Rock: Fluvial processes in Bedrock channels, edited by: Thinkler, K. J. and Wohl, E. E., AGU, Washington D.C., 1998.

Ikeda, H.: Large-scale grooves formed by scour on cohesive mud surfaces, Bulletin of Environmental Research Center, the University of Tsukuba, Japan, 2, 91-95, 1978.

Iken, A.: Measurement of water pressure in moulins as partof a movement study of the White Glacier, Axel Heiberg Island, NWT, Canada, J. Glaciol., 11, 53-58, 1972.

Irvine-Fynn, T. D. L., Hodson, A. J., Moorman, B. J., Vatne, G., and Hubbard, A. L.: Polythermal glacier hydrology: A review, Rev. Geophys., 49, RG4002, doi:10.1029/2010RG000350, 2011.

Isenko, E.: Water levels and temperatures in moulins, and other hydrological observations at Bashkara Glacier in Caucasus, Russia, in September 2005, Bulletin of Glaciological Research, 23, 9599, 2006

Isenko, E. and Mavluydov, B. R.: On the intensity of ice melting in supraglacial and englacial channels, Bulletin of Glaciological Research, 19, 93-99, 2002.

Isenko, E., Naruse, R., and Mavlyudov, B.: Water temperature in englacial and supraglacial channels: Change along the flow and contribution to ice melting on the channel wall, Cold Reg. Sci. Technol., 42, 53-62, 2005.

James, T. D., Murray, T., Barrand, N. E., Sykes, H. J., Fox, A. J., and King, M. A.: Observations of enhanced thinning in the upper reaches of Svalbard glaciers, The Cryosphere, 6, 1369-1381, doi:10.5194/tc-6-1369-2012, 2012.

Jansen, J. D.: Flood magnitude-frequency and lithologic control on bedrock river incision in post-orogenic terrain, Geomorphology, 82, 39-57, doi:10.1016/j.geomorph.2005.08.018, 2006.

Jarosch, A. H. and Gudmundsson, M. T.: A numerical model for meltwater channel evolution in glaciers, The Cryosphere, 6, 493503, doi:10.5194/tc-6-493-2012, 2012.

Jennings, S. J. A., Hambrey, M. J., Glasser, N. F., James, T. D., and Hubbard, B.: Structural glaciology of Austre Brøggerbreen, northwest Svalbard, Journal of Maps, 1-7, doi:10.1080/17445647.2015.1076744 (last access: 1 September 2015), 2015.

Karlstrom, L., Gajjar, P., and Manga, M.: Meander formation in supraglacial streams, J. Geophys. Res.-Earth, 118, 1897-1907, doi:10.1002/jgrf.20135, 2013.

Knighton, A. D.: Meandering Habit of Supraglacial Streams, Geol. Soc. Am. Bull., 83, 201-204, 1972.

Knighton, A. D.: Channel form and flow characteristics of supraglacial streams, Austre Okstindbreen, Norway, Arctic Alpine Res., 13, 295-306, 1981.

Knighton, A. D.: Channel form adjustment in supraglacial streams, Austre Okstindbreen, Norway, Arctic Alpine Res., 17, 451-466, 1985.

Kohler, J., James, T. D., Murray, T., Nuth, C., Brandt, O., Barrand, N. E., Aas, H. F., and Luckman, A.: Acceleration in thinning rate on western Svalbard glaciers, Geophys. Res. Lett., 34, L18502, doi:10.1029/2007gl030681, 2007.

König, M., Kohler, J., and Nuth, C.: Glacier Area Outlines Svalbard, edited by: Institute, N. P., Norwegian Polar Institute, Tromsø, 2013. 
Kostrzewski, A. and Zwoliñski, Z.: Hydraulic geometry of a supraglacial stream, Quaestiones Geographicae, 4, 165-176, available at: http://www.staff.amu.edu.pl/ zbzw/gh/gh1.htm, last access: 9 June 2015, 1995.

Lamb, M. P., Howard, A. D., Dietrich, W. E., and Perron, J. T.: Formation of amphitheater-headed valleys by waterfall erosion after large-scale slumping on Hawai'i, Bull Geol. Soc. Am., 119, 805-822, doi:10.1130/B25986.1, 2007.

Larue, J.-P.: Effects of tectonics and lithology on long profiles of 16 rivers of the southern Central Massif border between the Aude and the Orb (France), Geomorphology, 93, 343-367, doi:10.1016/j.geomorph.2007.03.003, 2008.

Leopold, L. B., Bagnold, R. A., Wolman, M. G., and Brush, L. M.: Flow Resistance in Sinuous or Irregular Channels, USGS, Washington D.C., 134 pp., 1960.

Lock, G. S. N.: The Growth and Decay of Ice, Cambridge University Press, Cambridge, UK, 1990.

Loget, N. and Van Den Driessche, J.: Wave train model for knickpoint migration, Geomorphology, 106, 376-382, doi:10.1016/j.geomorph.2008.10.017, 2009.

Mantelli, E., Camporeale, C., and Ridolfi, L.: Supraglacial channel inception: Modeling and processes, Water Resour. Res., 51, 7044-7063, doi:10.1002/2015WR017075, 2015.

Marston, R. A.: Supraglacial Stream Dynamics on the Juneau Icefield, Ann. Assoc. Am. Geogr., 73, 597-608, 1983.

Mason, J. P. and Arumugam, K.: Free Jet Scour Below Dams and Flip Buckets, J. Hydraul. Eng.-ASCE, 111, 220-235, doi:10.1061/(ASCE)0733-9429(1985)111:2(220), 1985.

Mavlyudov, B.: Glacier karst, why it is important to research, Acta Carsologica, 35, 55-67, 2006.

Mavlyudov, B. R.: About new type of subglacial channels, in: Glacier Cave and Glacial Karst in High Mountains and Polar Regions, edited by: Mavlyudov, B. R., Institute of Geography RAS, Moscow, 54-60, 2005.

McGrath, D., Colgan, W., Steffen, K., Lauffenburger, P., and Ba$\log$, J.: Assessing the summer water budget of a moulin basin in the Sermeq Avannarleq ablation region, Greenland ice sheet, J. Glaciol., 57, 954-964, 2011.

Miller, J. R.: The Influence of Bedrock Geology on Knickpoint Development and Channel-Bed Degradation along Downcutting Streams in South-Central Indiana, J. Geol., 99, 591-605, 1991.

Milzow, C., Molnar, P., McArdell, B. W., and Burlando, P.: Spatial organization in the step-pool structure of a steep mountain stream (Vogelbach, Switzerland), Water Resour. Res., 42, W04418, doi:10.1029/2004WR003870, 2006.

Molnar, P., Densmore, A. L., McArdell, B. W., Turowski, J. M., and Burlando, P.: Analysis of changes in the steppool morphology and channel profile of a steep mountain stream following a large flood, Geomorphology, 124, 85-94, doi:10.1016/j.geomorph.2010.08.014, 2010.

Montgomery, D. R. and Buffington, J. M.: Channel-reach morphology in mountain drainage basins, Geol. Soc. Am. Bull., 109, 596-611, 1997.

Müller, D.: Incision and Closure Processes of Meltwater Channels on the Glacier Longyearbreen, Spitsbergen, MS thesis Master Thesis, Institut für Geoökologie, Technische Universität Braunschweig, Braunschweig, 102 pp., 2007.

Myreng, S.: Characteristics and long-term evolution of an englacial meltwater channel in an cold-based glacier, Austre Brøgger- breen, Svalbard, MS thesis, Dept. of Geography Norwegian University of Science and Technology, Trondheim, 76 pp., 2015.

Naegeli, K., Lovell, H., Zemp, M., and Benn, D. I.: Dendritic Subglacial Drainage Systems in Cold Glaciers Formed by Cut-and-Closure Processes, Geogr. Ann. A, 96, 591-608, doi:10.1111/geoa.12059, 2014.

Nowak, A. and Hodson, A.: Hydrological response of a High-Arctic catchment to changing climate over the past 35 years: a case study of Bayelva watershed, Svalbard, Polar Res., 32, 19691, doi:10.3402/polar.v32i0.19691, 2013.

Nye, J. F.: The Flow Law of Ice from Measurements in Glacier Tunnels, Laboratory Experiments and the Jungfraufirn Borehole Experiment, P. Roy. Soc. Lond. Ser.-A, 219, 477-489, doi:10.1098/rspa.1953.0161, 1953.

Pagliara, S. and Hager, W.: Hydraulics of Plane Plunge Pool Scour, J. Hydraul. Eng.-ASCE, 132, 450-461, doi:10.1061/(ASCE)0733-9429(2006)132:5(450), 2006.

Parker, G.: Meandering of supraglacial melt streams, Water Resour. Res., 11, 551-552, 1975.

Penck, W. O.: Die piedmontflachen des sudlichen schwartzwaldes, Zeitschrift der Gesellschaft für Erdkunde zu Berlin, 1, 81-108, 1925.

Peterka, A. J.: Hydraulic design of stilling basins and energy dissipators, United States Department of the Interior, Denver, Colorado, 240 pp., 1963.

Peterson, D. F. and Mohanty, P. K.: Flume studies of flow in steep, rough channels, J. Hydr. Eng. Div.-ASCE, 86, 55-76, 1960.

Phillips, J. D., McCormack, S., Duan, J., Russo, J. P., Schumacher, A. M., Tripathi, G. N., Brockman, R. B., Mays, A. B., and Pulugurtha, S.: Origin and interpretation of knickpoints in the Big South Fork River basin, Kentucky-Tennessee, Geomorphology, 114, 188-198, doi:10.1016/j.geomorph.2009.06.023, 2010.

Phillips, R. T. J. and Desloges, J. R.: Glacially conditioned specific stream powers in low-relief river catchments of the southern Laurentian Great Lakes, Geomorphology, 206, 271-287, doi:10.1016/j.geomorph.2013.09.030, 2013.

Piccini, L., Romeo, A., and Badino, G.: Moulins and marginal contact caves in the Gornergletcher, Switzerland, Nimbus 23-24, 94-99, 2000.

Pinchak, A. C.: Diurnal flow variations, thermal erosion and evolution of supraglacial meltwater streams, in: A principles study of factors affecting the hydrological balance of the Lemon Glacier system and adjacent sectors of the Juneau Icefield, southeastern Alaska, 1965-1969, edited by: Miller, M., Inst. Water Res., Michigan State University, East Lansing, Michigan, Technical Report No. 33, 1972.

Porter, P. R., Vatne, G., Ng, F., and Irvine-Fynn, T. D. L.: Icemarginal sediment delivery to the surface of a High-Arctic glacier: Austre Brøggerbreen, Svalbard., Geogr. Ann. A, 92, $437-$ 449, doi:10.1111/j.1468-0459.2010.00406.x, 2010.

Pulina, M.: Glacierkarst phenomena in Spitsbergen, Norsk Geogr. Tidsskr., 38, 163-168, doi:10.1080/00291958408552121, 1984.

Pulina, M. and Rehak, J.: Glacier Caves in Spitsbergen, 1st International Symposium of Glacier Caves and Karst in Polar Regions, 1-5 October 1991, Madrid, 93-117, 1991.

Raymond, C. F. and Nolan, M. A. T. T.: Drainage of a glacial lake through an ice spillway, IAHS-AISH P., 264, 199-210, 2000.

Řehák, J., Ouhrabka, V., and Braun, J.: New information about the interior drainage of subpolar glaciers and the structure of me- 
dial moraines of the southwest Spitsbergen, Studia Carsologica (Czech Academy of Science), 1, 14-56, 1990.

Reynaud, L. and Moreau, L.: Moulins glaciaires des glaciers tempérés et froids de 1986 à 1994 (mer de glace et Groenland), morphologie et techniques de meures de la déformation de la glace, Actes du $3^{\circ}$ symposium International cavités glaciaires et cryokarst en régions polaires et de haute montagne, 1-6 November 1994, Camonix, 109-113, 1994.

Richardson, K., Carling, P. A.: A typology of sculpted forms in open bedrock channels, Geol. Soc. Am., Boulder, CO, USA, Special Papers 392, 2005.

Röthlisberger, H. and Lang, H.: Glacier Hydrology, in: Glaciofluvial sediment transfer: An Alpine perspective, edited by: Gurnell, A. and Clark, M. J., John Wiley and Sons, New York, 1987.

Schroeder, J.: Les moulins du glacier Hans de 1988a 1992, Cavites glaciaires et cryokarst en regions polaires et de haut montagne, Chamonix, France, 1994.

Schroeder, J.: Hans glacier moulins observed from 1988 to 1992, Svalbard, Norsk Geogr. Tidsskr., 52, 79-88, 1998.

Schroeder, J.: Moulins of a glacier seen as a thermal anomaly, in: Karst and CryoKarst: Joint Proceedings of the 25th Spelological School and the 8th International GLACKIPR Symposium, Katowice, Poland, 10-16 February 2007, 65-74, 2007.

Shreve, R. L.: Movement of water in glaciers, J. Glaciol., 11, 205214, 1972.

Shumm, S. A., Dumont, J. F., and Holbrook, J. M.: Active tectonics and alluvial rivers, Cambridge University Press, Cambridge, UK, 2000.

Sklar, L. S. and Dietrich, W. E.: Sediment and rock strength controls on river incision into bedrock, Geology, 29, 1087, doi:10.1130/0091-7613(2001)029<1087:SARSCO>2.0.CO;2, 2001.

Smith, L. C., Chu, V. W., Yang, K., Gleason, C. J., Pitcher, L. H., Rennermalm, A. K., Legleiter, C. J., Behar, A. E., Overstreet, B. T., Moustafa, S. E., Tedesco, M., Forster, R. R., LeWinter, A. L., Finnegan, D. C., Sheng, Y., and Balog, J.: Efficient meltwater drainage through supraglacial streams and rivers on the southwest Greenland ice sheet, P. Natl. Acad. Sci. USA, 112, 1001-1006, doi:10.1073/pnas.1413024112, 2015.

Stein, O. R., Julien, P. Y., and Alonso, C. V.: Mechanics of jet scour downstream of a headcut, J. Hydraul. Res., 31, 723-738, doi:10.1080/00221689309498814, 1993.

Stenborg, T.: Glacier drainage connected with ice structures, Geogr. Ann. A, 50, 25-53, 1968.

Stock, J. and Pinchak, A. C.: Diurnal discharge fluctuations and streambed ablation in a supraglacial stream on the VaughanLewis and Gilkey Glaciers, Juneau Icefield, Alaska, Proceedings of the ASME Heat Transfer and Fluids Engineering Divisions, 285-292, 1995.

Stuart, G., Murray, T., Gamble, N., Hayes, K., and Hodson, A.: Characterization of englacial channels by ground-penetrating radar: An example from austre Broggerbreen, Svalbard, J. Geophys. Res., 108, 2525, doi:10.1029/2003JB002435, 2003.

Turowski, J. M., Yager, E. M., Badoux, A., Rickenmann, D., and Molnar, P.: The impact of exceptional events on erosion, bedload transport and channel stability in a step-pool channel, Earth Surf. Proc. Land., 34, 1661-1673, doi:10.1002/esp.1855, 2009.

Vallé, B. L. and Pasternack, G. B.: Submerged and unsubmerged natural hydraulic jumps in a bedrock step- pool mountain channel, Geomorphology, 82, 146-159, doi:10.1016/j.geomorph.2005.09.024, 2006.

Vatne, G.: Geometry of englacial water conduits, Austre Brøggerbreen, Svalbard, Norsk Geogr. Tidsskr., 55, 85-93, 2001.

Vatne, G. and Refsnes, I.: Channel pattern and geometry of englacial conduits, Glacier Caves and Karst in Polar Regions, 6th International Symposium, 3-8 September 2003, Ny-Ålesund, Svalbard, 181-188, 2003.

Venditti, J. G., Rennie, C. D., Bomhof, J., Bradley, R. W., Little, M., and Church, M.: Flow in bedrock canyons, Nature, 513, 534537, doi:10.1038/nature13779, 2014.

Whipple, K. X.: Bedrock rivers and the geomorphology of active orogens, Annu. Rev. Earth Pl. Sc., 32, 151-185, doi:10.1146/annurev.earth.32.101802.120356, 2004.

Whipple, K. X. and Tucker, G. E.: Implications of sediment-fluxdependentriver incision models for landscape evolution, J. Geophys. Res., 107, 3-1-3-20, 2002.

Whipple, K. X., Hancock, G. S., and Anderson, R. S.: River incision into bedrock: Mechanics and relative efficacy of plucking, abrasion, and cavitation, Geol. Soc. Am. Bull., 112, 490-503, 10.1130/0016-7606(2000)112<490:riibma>2.0.co;2, 2000.

Whittaker, A. C., Cowie, P. A., Attal, M., Tucker, G. E., and Robberts, P. J.: Bedrock channel adjustment to tectonic forcing: implications for predicting river incision rates, Geology, 35, 103106, 2007.

Whittaker, J. G.: Sediment transport in step-pool streams, in: Sediment ransport in gravel-bed rivers, edited by: Thorne, C. R., Bathurst, J. C., and Hey, R. D., J. Wiley, Chichester, UK, 545582, 1987.

Wilcox, A. C., Wohl, E. E., Comiti, F., and Mao, L.: Hydraulics, morphology, and energy dissipation in an alpine step-pool channel, Water Resour. Res., 47, W07514, doi:10.1029/2010WR010192, 2011.

Wohl, E. E.: Bedrock Channel Incision along Piccaninny Creek, Australia, J. Geol., 101, 749-761, 1993.

Wohl, E. E.: Bedrock Channel Morphology in Relation to Erosional Processes, in: Rivers Over Rock: Fluvial Processes in Bedrock Channels, edited by: Tinkler, K. J. and Wohl, E. E., American Geophysical Union, Washington, D.C., 133-151, doi:10.1029/GM107p0133, 2013.

Wohl, E. E. and Grodek, T.: Channel bed-steps along Nahal Yael, Negev desert, Israel, Geomorphology, 9, 117-126, 1994.

Wohl, E. E., Thompson, D. M., and Miller, A. J.: Canyons with undulating walls, Geol. Soc. Am. Bull., 111, 949-959, doi:10.1130/0016-7606(1999)111<0949:cwuw>2.3.co;2, 1999.

Young, R. W.: Waterfalls: form and process, Z. Geomorphol. Supp., 55, 81-95, 1985.

Zeller, J.: Meandering channels in Switzerland, IAHS-IASH P., 75, 174-186, 1967.

Zotikov, I. A.: Thermal physics of glacial sheets, Gidrometeoizdat, Leningrad, 288 pp., 1982 (in Russian). 